\title{
The Renaissance Footprint: The Material Trace in Print Culture from Dürer to Spenser.
}

\section{The Printing Foot}

Literary culture is deeply invested in the hand. As Jacques Derrida put it "the history of writing is erected on the base of the history of the grammé as an adventure of relationships between the face and the hand."1 The study of literature as writing, the marks made by the pen, is a study of the pressure exerted through the hand that comes to characterise both the manuscripts produced and the scripts in which they are rendered. The insistence upon the hand in the field of literature, on literature as handiwork, is only one symptom of the wider significance accorded to what Aristotle termed "the instrument of instruments:" the hand is not only a figure for the authorial function (in both literature and the graphic arts) but a metonym for all human agency. ${ }^{2}$ Without contesting the cultural pre-eminence of the manual within western culture, this essay directs attention to a relatively neglected member, shifting the focus from the act of writing to the scene of printing in order to address the Renaissance footprint and its place within the production and consumption of culture.

The foot is the human body's primary printing instrument. Its impressions constitute a fundamental effect of human presence on earth. The oldest prints of a hominid foot (somewhere between 3.6 and 3.85 million years old) were discovered in Laetoli, Tanzania, in 1976 and represent the earliest material trace of bipedal humanity. ${ }^{3}$ The sequence of steps imprinted in a layer of volcanic ash hardened by sudden rain was preserved by a fresh ashfall shortly afterwards. In the usual way of things the mark left by the human foot is 
impermanent: in snow, in ash, in mud or in sand, such tracks do not ordinarily survive long. The earliest comparable footprints discovered in Europe were exposed to view by coastal erosion at Happisburgh, Norfolk in May 2013. After enduring some 800,000 to 1 million years undercover, within a month the tide had washed them away. ${ }^{4}$ Such erasure is more characteristic of the everyday temporality of footprints as passing marks which participate in the material conditions of their site. As the anthropologist Tim Ingold has written, the impressive texture of footprints is "bound to the very dynamics of the ground to which they belong." It is this quality of the footprint as embedded within its environment that has made it a widely-shared symbol of located knowledge. Alice Leggat records how a member of the Thcho community in Northern Canada criticised the authority of outsiders who had not engaged with the environment or shared its stories observing starkly "There are no footprints of theirs, but still they talk." ${ }^{\prime}$ For the Tchcho people as for many other cultures the footprint is a responsive mark denoting a social system of knowledge that "binds people to place."7

The early modern period had its own social practices through which to understand the footprint and the forms of embedded knowledge it could represent. The custom of perambulation, whether of parish, manor, or common land, provided one performative mode for the transmission of communal knowledge via the mark of the foot. Selected male youths re-traced the steps of their elders in this annual rite in order that those footprints should be reinscribed in the communal memory. ${ }^{8}$ The conceptual currency of the perambulation footprint was such that it was widely appropriated as a textual trope. ${ }^{9}$ When London's Remembrancer Sir Thomas Norton prepared a manuscript calendar of civic customs and duties for the new Lord Mayor in 1574, he framed it is as "the doinges of $\mathrm{yo}^{\mathrm{r}} \mathrm{p}^{\mathrm{r}}$ decessors recorded, their steppes traced out, and sett before you." ${ }^{10}$ In a vivid sense, then, members of early modern communities learned to conceptualise an ongoing presence of ancestors in the environment 
under the sign of the footprint. The same sign also encompassed naturally occurring features in the landscape and man-made markings in which they recognised the traces left in their midst by legendary figures. The footprint-shaped forms at Dunadd, Argyll, for example, are typical of ritually significant marks associated with the inauguration of early rulers in Scotland and Ireland. ${ }^{11}$ Many similar features across Europe were appropriated to serve a Christianised perception of "the immanence of the holy in the natural world" by conjuring the vivid presence of native or adopted saints within the familiar environment. ${ }^{12}$ In this way the pre-Reformation landscape of Britain and Ireland came to accommodate such marks as the footprints of St Midreth in Kent, St Columba in Kintyre, St Patrick in Donegal, St Pirin in Cornwall and a rock impression of "St Agnes ys fote" in the same county. ${ }^{13}$ These holy footprints became the focus of devotional cults with shrines built that celebrated their thaumaturgic properties and re-framed their place within the landscape. As the conduits of miraculous power, the focus of local customs of commemoration, and the object of spatial devotions, these evocative marks functioned as a form of topographic relic.

Where the Renaissance inherited a rich culture of the footprint that encompassed collective social practices and metaphorical appropriations, the present essay traces how these cultural meanings inscribed within the European imagination were affected by the rise of print in the sixteenth century, taking its cue from Margareta de Grazia's seminal account of how "the mechanics of the imprint... worked itself into the semantics of the period." 14 In the essay 'Imprints' de Grazia demonstrated that the conceptualisation of printing in the early modern period was informed by the long history of impression and inscription as cultural models. She was able to show how the arrival of the printing press "materialized and mechanized the metaphorics of the signet and wax," a symbolic configuration used since Plato to figure the transfer and retention of knowledge, and for almost as long overlaid with biological and 
corporeal associations that resulted in a pattern of semantic interplay between sexual and textual reproduction. ${ }^{15}$ The capacity of new reproductive mechanisms to revitalise this ancient complex of associations and become a model for understanding reproductive bodies and minds is a striking illustration of the impact of print, and its tools, technologies and practices, on the cultural imagination. In turning attention to the footprint, this essay examines a parallel impressive metaphor with widespread conceptual currency in the early modern period whose importance has hitherto been neglected. It is the argument of this essay that the reproductive technologies cited by de Grazia co-opted the sign of the footprint in ways that have not been recognised, freighting it with a symbolic surplus that resonates in the products of the sixteenth century press, from the devotional woodcut to the poetry of the printed book. As a marker of presence created through the dynamic transaction of the foot with a textural environment, the footprint foregrounds materiality and its appropriation in print culture focalises the mediation of matter in the imprinted work, affording an insight into how the authors and readers of print pursued the material trace across the printed page.

Associating the impact of print with the impress of the foot might be held to conflict with the footprint's role as a figuration of embedded knowledge. Tim Ingold and Lee Vergunst have sought to distinguish the footprint from the activity of "printmaking." In contrast to the work of the flexible foot on yielding ground, "the printer," they argue, "stamps a design that has already been engraved or set, upon an absolutely flat, homogenous and resistant surface. The surface itself is not deformed by this movement." 16 Ingold has been a key voice championing cultures of and through the foot, and this observation is part of an approach that equates walking practices with the form and process that inhere in the drawing of a line, but the opposition he seeks to establish is alien to the early modern period. ${ }^{17}$ In particular his account of printmaking does not reflect the material contingencies of sixteenth-century print 
production, nor the place of printing in the contemporary imagination. Far from being resistant, printing is grounded directly on "the crucial quality of paper - its absorbency," a material disposition to which early modern readers alive to the textural fabric of contemporary paper stocks were well attuned. ${ }^{18}$ From a material perspective both relief printing (encompassing the use of letter press and woodcut blocks) and the contrasting technique of intaglio printing from copper plate, are inherently deformative. As Randall McLeod has shown in a brilliant excavation of the impact of print, the printed page has its own three dimensional topography, comprising a little world of craters and buttes produced by the letter press.

As pressure from the platen transmitted downward onto the paper increases, the types in the bed of the press push their inked faces up into the yielding paper and cushioning blankets. Since paper is moistened before printing, its fibres are usually able in this duress to give and slide over one another without tearing, and so the medium stretches and moulds locally to the individual shapes of the typefaces biting into it. ${ }^{19}$

In the environment of the printing house, the particular conditions that make paper a receptive and responsive partner in the process are deliberately induced in order that the type can not only print on but also impress itself into the fibrous mesh. In relief printing the letter, or the carved matrix of the woodcut, embeds itself into the yielding surface, imitating the transaction between foot and ground. Even the later-developing process of intaglio printing used for copperplate engravings involves deformation, albeit of an inverse kind, as great force is transmitted through a rolling press "to mould the dampened paper into the engraved lines." ${ }^{20}$ Understanding printing as a dynamic physical process brings it closer to the act of 
footprinting than Ingold's formulation would concede. In so doing it restores to view the analogy recognised by the early modern imagination between the printing press and printing foot. The corporeal terminology of the press is as evocative in its use of the foot, as it is rich in the gendered, phallo-centric associations identified by de Grazia in early descriptions of the printing process such as Joseph Moxon's Mechanick Exercises (1683). As presented by Moxon and his contemporaries, it is the toe of the spindle that applies downward pressure to the platen to bring paper into contact with type. To generate the necessary pressure, the printshop worker presses his foot against the foot-step placed at floor level and leans backwards, leveraging the force driving through his leg like a rower in order to pull towards himself the wooden bar that winds the spindle down. ${ }^{21}$ The nomenclature identifies the pedestrian strain within the mechanics of printing. It is no exaggeration to say that the printed page is produced by the effect of twin feet as the pressure of the printer's sole on the foot-step is displaced and transferred through the toe of the mechanical spindle. This conjunction is nicely captured in the woodcut colophon used from 1520 by the Paris printer Jodocus Badius (fig. 1) depicting a printing house at work in which we find the bare foot of the pressman centre stage, directly beneath the toe of the spindle. Coincident with the spread of printing technology the terminology describing the marks of the foot begins to become equated with print: the word footprint itself is a coinage that emerges with the rise of the printing press. The earlier English terms footing and footstep do not distinguish between the action of stepping, the mark it leaves, and indeed the sound it makes. ${ }^{22}$ The discursive exchange between these two kinds of printing via the foot - on the earth and in the printshop provides a pointer to the ways that the spread of printing appropriated the play of early modern feet on the ground, "materialis[ing] and mechanis[ing]," to use de Grazia's terms, the "metaphorics" of footing. To examine that process it is necessary to begin with the sacred 
footprint that provided an important precedent connecting the mark of the foot with the rhetorics and practices of reproduction.

\section{Relics and Reproduction}

From the later middle ages into the early Renaissance the spiritual power of holy relics was exercised through an increasing variety of media, in forms of material translation that would pave the way for the new cultural resonances of the footprint brought into play by the advent of print. The Christian culture of relic veneration that emerged in the fourth century out of localised memorial practices marking the burial sites of Christian saints would remain rooted in regional custom into the medieval period. ${ }^{23}$ Within the order of relics a hierarchy existed. The primary form was the corporeal relic that brought a worshipper into contact with the physical remains of a saint, and through that interaction gave access to the presence of God. Despite doctrinal resistance, relic ritual performances make clear that the presence of the saint was understood to inhere in the bones of the deceased. ${ }^{24}$ The same was true of the class of secondary relics comprising anything with which the saint had come into contact, ranging from clothing to items prominent within a saint's life story. There was also a further category of contact relics sanctified through subsequent contact with corpse or tomb whereby the church could generate new relic matter. Such practices as the ritualised drawing of a piece of linen or silk over the tomb or bones of a dead saint were used to produce a brandea, freshly endowed with the effective presence of the saint.$^{25}$ Versions of this practice were operating at Rome's pilgrim churches in the 1580s, when Anthony Munday mocked the ritualised touching of pilgrims' beads against reliquaries through which, as he explained derisively, "the Beades steal a terrible deale of holyness out of those bones." 26 The rise in indulgences tied to the visiting, touching or viewing of relics had driven an acquisitive interest, 
stimulating a wave of choreographed holy archaeology from the twelfth century, as religious institutions enthusiastically uncovered the remains of local saints. ${ }^{27}$ Yet promotion of the universal accessibility of Christ over affiliations to regional saints by the later medieval church had particular consequences for the relic cult. The very nature of Christ's Ascension, rising into a cloud with his resurrected body intact, precluded the possibility of venerating any other body parts than those separated from him during the course of his life on earth. As Jean Calvin (1509-1564) put it in his withering assault on the culture of relic-worship delivered in the form of a mock register of relics: "because they coulde not saye that they had the naturall body [of Christ], they haue gathered in stede therof thousands of other trifles, to supplye this want." 28 For a religion in which "the coming of the divine into matter" formed the very cornerstone of salvation, the absence of primary relics of the Saviour beyond corporeal discards such as foreskin, milk teeth and hair, presented a series of ritual and representational challenges. ${ }^{29}$ Transposing the power of holy matter onto the idea of the real presence in the Eucharist and treating the consecrated host in the manner of a relic, as well as cultivating devotion to the relic of Christ's blood, can be seen as responses to this problem. ${ }^{30}$ Nevertheless there remained a strong desire to trace Christ's presence through his material impressions upon the world that is evidenced in contemporary concern with Christ's footprints.

Footprint relics of Christ are predominantly associated with miraculous appearances after his death. Some functioned as topographic relics, such as " $y^{e}$ steppys of the fot of oure lord Ihū Criste" displayed at the Domine Quo Vadis chapel by San Sebastiano on the Appian Way where, as Richard Arnold recorded in 1523, "there is M. yere of pardon" for seeing them. ${ }^{31}$ Commemorating an Apocryphal episode when the fleeing Peter met Christ heading in the other direction who told him he was going to Rome to be crucified again, the site-specific 
relic offers a focus for ritual rehearsals of Peter's transformational encounter with the rematerialised Christ: a juncture at which Peter changed course, returning to the city to accept his martyrdom. It thus drew meaning from a rich topographical context that invited visitors to play out the spiritual drama of a turning point in the path of true faith, and rewarded that rehearsal with remission of sin. However, the most celebrated footprints of the Saviour, were connected with Christ's ascension from the Mount of Olives; the last episode of The Passion to play out on earth. These miraculous footsteps functioned particularly as a material sign of divine incorporation. In the words of a sermon in the Anglo-Saxon Blickling Homilies: "Our Lord let his holy feet sink into the earth there for a perpetual remembrance to men, when that he after his holy passion would take his human nature into heaven." 32 While no Biblical source describes the leaving behind of footprints at the Ascension scene - neither the two gospel references (Mark 16:19, Luke 24:50-53), nor the more extensive account in Acts 1:911 -a complex of textual legends and material manifestations attest to a longstanding concern with the prospect. The earliest report, from Sulcipius Severus in $402 \mathrm{CE}$, describes a persistent set of footprints in the dust that proved magically resistant when attempts were made to pave the floor of the Chapel of the Ascension. ${ }^{33}$ Details of the miraculously regenerating footprints recur in several histories (whence they would later resurface in the Legenda Aurea), and in the accounts of early pilgrims who brought back small amounts of the holy dust among their mementoes. ${ }^{34}$ At the close of the tenth century the author of the Blickling Homilies is still describing how "the earth is daily removed from the footsteps and taken as a relic widely throughout the earth," in spite of which "they ever remain as entire, and of the same appearance as that in which they were first impressed upon the earth." 35 By the twelfth century, however, a new kind of pilgrimage experience supported by generous indulgences had developed around the Mount of Olives site. In the subsequent wave of pilgrimage testimony the material form of Christ's footprints has been converted from 
impressions sunk into the dust beneath the chapel floor, to foot marks upon a raised rock. ${ }^{36}$ Both the miraculously regenerative nature of the dust and the material translation to stone are features occurring in other relic histories whereby the superabundance of Ascension footprints or fragments of the True Cross becomes associated with biblical acts of miraculous reproduction, for which Christ's feeding of the 5000 provides the template. ${ }^{37}$ Material instability persists in post-twelfth century itineraries where despite petrification , reports from pilgrims who sought the close physical contact customary in relic devotion differ over whether the left, the right, or indeed both footprints were preserved in the chapel. ${ }^{38}$ The multiple examples of Christ's Ascension footprints in the form of relic stones deposited in churches highlight the ways in which the holy footprint could be translated from an embedded presence in the sacred geography of the Holy Land, to a portable and reproducible relic object available for appropriation into ritual topographies across Christendom, even on occasions overwriting local markers in the process. ${ }^{39}$ Calvin would list examples shown "at Poitiers at S. Raguonde another at Soison, another in Arles." ${ }^{40}$ In England Westminster Abbey boasted its own "stone with the impression of Christ's feet at his Ascension to heaven," presented by Henry III in 1249 and swiftly recognised with multiple indulgences. ${ }^{41}$

If the footprints of Christ were widely encountered as relics throughout the medieval and early modern period in sacred spaces from the Mount of Olives to Westminster Abbey and the Roman suburbs, they were also experienced via imaginative practices such as the devotional habits of virtual pilgrimage and rehearsal of the Passion. ${ }^{42}$ The story of Christ's passion had long been intertwined with the veneration of a series of symbolic objects known as the Arma Christi and his bloody footprint on the route to Calvary is sometimes included amongst the signs of his final suffering. ${ }^{43}$ A remarkable painted ivory devotional booklet likely produced in Cologne c.1330-40 combines illustrations of Christ's passion with a 
depiction of the Arma that features three blood-speckled footprints making their way along the lower border (fig. 2). Examples of the motif are found in stone tablet, wood relief, wall paintings and wooden altar tables from the thirteenth to the fifteenth century. ${ }^{44}$ Unlike other of the Arma Christi, the bloody footprints had no extant material referent and no pilgrims' accounts report their miraculous survival in situ. The footprints in blood were rather a representational device and in England they appeared in verbal as well as visual form. 'O Vernicle', a late fourteenth century poetic meditation on the Arma Christi that circulated throughout the 1400s and reached print around 1523, devotes a verse to the spectacle, describing how "Pin fote steppis suete and gode/ Were sene thorow schedyyng of pi blode" with several of the extant manuscripts featuring illustrations of the bloody prints before the city gates. ${ }^{45}$ 'O Vernicle''s reflection on the salvific effect of Christ's bloody footprints has been plausibly linked with the expanding practice of imagined pilgrimage, for which contemporary schedules of indulgence set out tariffs of remission. ${ }^{46}$ In this guise the bloody footprints function as aids in the imaginative locating of Christ's route to the cross and rehearsal of the stages of the Passion, evoking the persistence of Christ's course in despite of suffering and affliction.

To these modes of encounter, as relic object and imaginative rehearsal, the printed image was a significant new addition although early woodcuts downplayed their status as prints, seeking rather to borrow "some of the prestige of the handmade artefact." 47 This is seen in the singleleaf German devotional woodcut depicting the Mass of St Gregory, dated to 1420-30 (fig. 3) whose depiction of Christ's bloody footprints has a good claim to be the earliest extant image of footprints printed on paper - and perhaps amongst the earliest of all paper prints. ${ }^{48}$ The combination of elements from various iconographic traditions has led art historians to identify unresolved tensions in the visual and theological programme behind the woodcut's 
design attributable to its early date in the working out of a representational language of the Gregory Mass. ${ }^{49}$ Use of the footstep ladder motif among the Arma Christi can also be seen in this light. Noticeably the three footprints represented in bold outline are of contrasting sizes and reproduced out of sequence - left, left, right - in a stuttering waltz that suggests a design not fully adjusted to the developing material techniques of the woodcut print. Ultimately, although the bloody footprints form a recognisable Arma Christi motif across a range of media, with particular prominence among English manuscript transmission networks, they appear in few printed images of the Gregory Mass. ${ }^{50}$ Print would bring a powerful new semiotic resonance to the representation of Christ's footprints, but proceeding via another route.

The printing process was itself analogous to forms of material reproduction which invested authority into newly redefined matter: the stamping of seals or coinage were prominent examples, but particularly evocative were those actions which gave form to holy matter such as the use of wafering irons to imprint designs upon the Eucharistic wafer or the rituals through which new contact relics were printed off from sacred tombs, or reliquaries. ${ }^{51}$ The representational subject that most obviously evokes that association is the Sudarium, the cloth with which Saint Veronica is supposed to have wiped the brow of Christ on his way to Calvary only to find the true image of the Saviour's face - the vera icon, in the popular but false contemporary etymology - had miraculously imprinted itself upon the fabric. The Sudarium, or Veronica, preserved at St Peter's in Rome has thus been seen as the Western prototype for the authenticated image of Christ (the counterpart to the Mandylion of the Eastern church) but it was also the embodiment of a divinely authenticated process of reproduction: the acheiropoieton, an image not made by human hands. ${ }^{52}$ The charismatic authority of the legend licensed the proliferation of Sudarium images in churches across 
Europe as "further miracles of unmediated reproduction, in which a cloth or a parchment covering the original likeness [had been] imprinted with an equally authentic Holy Face." ${ }^{, 53}$ A directly impressed likeness of Christ bequeathed to his followers, the Sudarium provided a potent mythos of representation that was particularly suited to the fledgling art of woodcut printmaking, enabling the image to co-opt the resonance of the medium itself. Renaissance print-makers began to realise the self-reflexive appeal of the Sudarium image from the later fifteenth century. As Lisa Pon has observed of a 1470 example from Hans Schlaffer of Ulm, "in laying the dampened sheet of paper on the carved wooden block charged with ink, the printer re-enacts Veronica's gesture of blotting the raised contours of Christ's damp face." The artist who would best exploit the potential of the Sudarium was Albrecht Dürer (14711528), a central figure in the establishment of printmaking as a prestige mode of visual consumption. ${ }^{55}$ Particularly significant among his many depictions of the subject in various media is that in the Small Passion series, one of four major woodcut collections issued by Dürer in 1511 (the others being the Large Passion, The Life of the Virgin and The Apocalypse) as the culmination of his ambitious experimentations in the potential of the form. ${ }^{56}$ Dürer's achievements of that year were as much innovations in publishing and bookmaking as the graphic arts: each featured the famously aggressive printing privilege in which he asserted not only his artistic credentials as creator of the images, but his rights as publisher. The Small Passion's colophon is even laid out on the page to form two triangles converging on the single word imprimere - a diagonal cruciform pattern that may be a response to rival printers' devices and suggests a remarkable level of coordinated design in the volume's production. ${ }^{57}$ For an artist-publisher so invested in shaping the forms of graphic consumption it was a richly symbolic move to insert into the Small Passion this early version of a subject that thematises the production by no human hand of the divine image. Dürer stages the process of divine production across two woodcuts. The first depicts Christ faltering 
beneath the weight of the cross, his face turned towards the woman who stretches out a cloth in her hands (fig. 4). The succeeding image is one of only three dated woodcuts in the series of 37, and shows Saint Veronica with the Sudarium standing between Peter and Paul (fig. 5) in a closed-off, windowless interior that stands out in contrast to the narrative sequence of the Passion. The contemplative detachment of the image following on from the scene of imprinting encourages the sense that Dürer is offering a reflexive commentary upon the process of representation, promoting an aestheticized semiotics of printing that translates the printed Small Passion itself into a devotional object with an integral spiritual charge. It is this integration of a materialised aesthetics of the printing press with a divine authorisation of true representation that gives particular significance to his depiction in the same series of the Ascension featuring the footprints of Christ (fig. 6).

Compositionally, Dürer's image of the Ascension looks back to an iconographic tradition of late Anglo Saxon origin dubbed the "Disappearing Christ" phenomenon, which depicts the Saviour at the moment of heavenward departure as he rises into a cloud, his feet only visible above the resolutely earth-bound apostles. ${ }^{58}$ Early examples do not include the footprints, which first appear in a distinct German tradition that depicts a raised stone with two impressions, but from the fourteenth century versions of the disappearing Christ composition feature footprints impressed directly into the hillside, with late medieval examples extant across Europe including a good number of fifteenth-century stained glass windows in England. ${ }^{59}$ As with the Sudarium, Dürer was not the first to render the subject in woodcut form. The composition occurs in some rudimentary German Passion scene prints of the 1450s, and more widely in editions of the Legenda Aurea printed across Europe from 1471, with multiple English versions appearing in several titles that incorporated the story of the passion. ${ }^{60}$ Even the finest of these, such as the larger block commissioned for the 1487 
edition of Caxton's translation (fig. 7), represent the footprint in a basic outline form. By contrast, Dürer drew the focus to the impress of the foot with a highly textured representation of the prints that brings the foot into play as a printing instrument, exploiting the symbolic potential of the reproductive process. There is a particular significance to separating the head of Christ, longstanding symbol of his divinity, from his feet, associated with his incarnation and humanity - a contrast delineated by Gregory the Great, who noted: "we can ... understand by his feet the mystery of his Incarnation, by which his divinity touched the earth because he took a body to himself." ${ }^{\prime 61}$ The exegetical tradition opposing head and foot provides a framework for understanding the twinned images of the divine face in the Sudarium and the Ascension with Christ's footprints as they feature in the Small Passion. In this context the corporeal materiality of Christ registers as a particular effect of the foot in print. The original woodblock (fig. 8) shows how this effect was created. The subtractional process of woodcutting requires the printing matter to stand forth with the hollowed out sections lending visual prominence to the central feature of the printed image: Christ's impression on earth. As Christ disappears into the heavens viewers of the image are left to ask with the apostles what has been left behind, and to reflect on the mystery of His incarnation on earth. The footprint is the focalizing point of that enquiry and its printed image is generated by a shaped wooden foot - not the heavy outline of the early fifteenth century precursor, but a carefully contoured protuberance that treads into the paper in the act of printing. The devotional design of Dürer's Small Passion is dedicated to producing fresh imprints that do not imitate so much as re-enact, through the mysterious material transaction of acheiropoietos, Christ's final terrestrial contact. In so doing Dürer's Nuremberg press printed off a form of affective contact relic for consumption by a devout print audience already familiar with the use of printed substitutes for relic objects to which indulgences could be attached for those unwilling, or unable, to make a pilgrimage in person. ${ }^{62}$ At the 
same time Dürer's prints were finding, and helping to create, a market for the collection of prints as high-end consumer goods.

Dürer's image would have a significant impact on the visual imagination of early modern Europe. With The Small Passion "the most widely circulated of all Durer's woodcuts," besides frequent re-printings it was also swiftly imitated in a range of formats. ${ }^{63}$ The Italian printmaker Marcantonio Raimondi (c.1480-c.1534) reportedly produced a first copy of the entire series within a year as well as an extant 1515 series substituting a blank cartellino for the famous "AD" monogram shortly after a foreigner was prosecuted in Nuremberg for selling prints with Durer's mark. ${ }^{64}$ In Regensburg Albrecht Altdorfer (1480-1538) included an Ascension that responded to Dürer's image in his miniature pocket book the Fall and Redemption of Man (1513). ${ }^{65}$ Copies and variations from leading exponents of the woodcutting art were much sought after by contemporaries such as Ferdinand Columbus who owned both the Dürer and Altdorder series, and at thriving print centres such as Antwerp where Dürer himself once sold 16 sets of the Small Passion. ${ }^{66}$ Available in separable form for display, the initial format of the devotional book was sustained in rudimentary imitations accompanied by printed textual meditations such as the Nuremberg Passional (c.1552) attributed to Virgil Solis (1514-1562) that features an Ascension with typeset verso (fig. 9). The influence of the Small Passion would even extend beyond print, exerting itself in a range of media, from relief sculpture to maiolica ware. ${ }^{67}$

Such widespread replication was transformative in other ways. Building on Hans Belting's thesis on the cultural transition from cult image to work of art, Christopher Wood has foregrounded the role of print in fatally disrupting "the system of substitution" characteristic of German culture, that had sustained a faith in local incarnations of both the sacred and the 
historical into the early renaissance period. Where, in this temporally fluid mode of conception "the substitutional paradigm licensed the beholder to act as if the copy were the icon," print, with its prolific multiplication along with its attempts at authentication, acknowledged a difference from the original that was formerly hidden from view, so producing a new scepticism over both artefacts and representations. ${ }^{68}$ The pressure applied to the credibility of the "system of substitution" was furthered by the historical and philological scholarship of humanism emerging from the presses of Europe. According to Wood, it was in these conditions and in this new space that the fictionality of the artwork began to take shape. Viewed in this light Dürer's image can be seen as a delicately poised creation that translates Christ's footprints from a referential substitution into a form of fictionality: a contact relic with no material referential link. But the effect of proliferation can also be seen in a work that came out of Nuremberg just ten years later, The Passional Christi und Anti-Christi (1521) that reimagined the passional in an oppositional format with images from the life of Christ facing depictions of the Pope. ${ }^{69}$ In woodcuts from Lucas Cranach and the brief textual legends of Philip Melancthon the work contrasts the humility of the barefoot, earthly Christ with the artificial elevation of a Pope shown distanced from the ground whether by dais, throne, or carried aloft in a litter by the labour of others, and culminates with the powerful juxtaposition of Christ's ascension to Heaven set against the Pope's fall, as anti-Christ, thrust down into Hell (fig. 10). Drawing upon the graphic imagination of the passion in a print format that Dürer had helped to establish, this hugely popular work sees Cranach's image of the Ascension re-frame the holy footprint within an antithetical structure that subverts veneration to stress the muddy mundanity of Christ's mortal embodiment. These two contrasting versions of Christ's footprints emerging from neighbouring Nuremberg presses a few years apart, were among the most influential woodcuts of the period, and serve to 
highlight the competing investment in the representation of the Ascension as devotional image, as high art object and as instrument of reforming propaganda.

\section{Reformation of the Footprint}

One might see the influence of Dürer's image in the 1520 colophon of Jodocus Badius (fig. 1), with its prominent naked foot echoing the imprinting of the press. Badius had after all christened his printshop the Praelum Ascensianum, or Ascensian Press - a play on words noted by contemporaries. ${ }^{70}$ Yet the colophon is also emblematic of change. One of the leading humanist printers of the period and a noted commentator, Badius was responsible for landmark classical editions including of Virgil and Lucan along with key contemporary texts including Erasmus' Adagia. For Erasmus he also printed In latinam Nove testamenti interpretaioners adnotationes (1505) incorporating the first printed text of Lorenzo Valla's Annotations which used humanist philological techniques to expose the material weaknesses of the Vulgate gospel and pave the way for the scriptural revolutions of the sixteenth century. ${ }^{71}$ In the medium of print, the subject of Christ's footprints became a focus for debates over the material mediation of faith that would prove central to Reformation culture. The tensions are evident in Erasmus' own Paraclesis, one of the foundational texts of Reformation scholarship, printed in 1516 as the preface to the Novum Instrumentum, his Greek and Latin edition of the New Testament used by both Luther and Tyndale for their translations into the vernacular. In this manifesto for an Erasmian philosophy of Christ the author provided the template for "a new Christian reader and a new mode of Christian reading," famously championing access to the Gospels for all social orders and the speakers of all tongues. ${ }^{72}$ At the climax of the Paraclesis, Erasmus proclaims the value of Scripture by setting the power of the text in contrast to the displayed object of devotion. The example he uses is Christ's footprints: 
If a man would shew us a steppe of Christes foote/ Good lorde/ how would wee knele and worshuppe it? And why do we not rather honoure his qwycke and lyvelye image which is most expresslye contayned in these bokes? ${ }^{73}$

Erasmus' doubts over relic devotion would be set out more fully in a dialogue from the Colloquies (1526), later selectively translated as Ye Pylgremage of Pure Deuotyon (1538) where his observationson the shrines at Walsingham and Canterbury provided matter for Thomas Cranmer's campaign to inculcate popular revulsion for relics. ${ }^{74}$ But the revolutionary force of the Paraclesis statement went beyond stirring disgust. Christ's footprints figure for Erasmus a religious disposition of unthinking genuflection that stands in the place of a more engaged form of spiritual access via the text. Claiming "the text [as] the receptacle of Christ 'fully present' - even more than in his human body or implicitly than in the sacrament," Erasmus raised a challenge to devotional practice that extended to the most sacred liturgical rites of the church, according primacy instead to a text which his own philological labours had removed from the authority of Rome. ${ }^{75}$

The words of the Paraclesis were to be of lasting influence on the radical reforming movement in England. First translated into English by Tyndale's sometime assistant William Roy (d. 1531(?)), and published by Tyndale's Antwerp printer, the pseudonymous "Hans Luft" in 1529 , it would circulate widely both as a separate work, and later as the preface to Tyndale's New Testament, in unlicensed versions $(1536,1542)$ as well as the Edwardian editions $(1549,1550)$ published in London, at the time when copies of Erasmus' Paraphrases were mandated for every parish in England. ${ }^{76}$ After Elizabeth's accession, the Paraclesis phrase would be absorbed into the guidance on scriptural study in the Seconde Tome of 
Homelyes (1563), a cornerstone of mainstream reformed doctrine that was required reading for every parish in England:

If one could shewe but the prynt of Chrystes foote, a great number I thinke, would fal downe and worship it: But to the holy scriptures, where we may see dayly (yf we wyll) I wyll not say the prynt of his feete onleye, but the whole shape and lyuely ymage of hym, alas we geue lytle reuerence or none at all. ${ }^{77}$

The authorised guidance builds on Erasmus' argument that the text of Scripture provided unmediated access to Christ, but reframes it in important ways. It is one of the paradoxes of the Paraclesis that despite championing access to the gospels in all tongues, Erasmus enshrined the value of scripture in a specific textual form in the premise that "the letters of the Greek text offer direct access to the original presence of the author."78 Similarly, Lutheran thought had assisted the transfer of devotional attention from relic to text by encouraging veneration for concrete forms of the sacred word, not least in the notion that the name of God in scripture contained the signified within it - an idea that appropriated something of the salvific power accorded to the Holy Name and its use imprinted into sacramental wafers. ${ }^{79}$ In adapting Erasmus, the Seconde Tome of Homelyes acknowledges an ongoing reverence for devotional objects, setting up an association rather than an opposition between holy matter and holy text which hinges upon the play of print to denote the material trace of Christ's presence, his imprint, construed as a quality contained within the printed scripture. The association may have been framed in terms of a metaphorical substitution, but the play on printing brings with it an attention to the book as materially impressed object only encouraged by the exhortation of the brethren to "embrace and reuerence Goddes holy bookes, the sacred Byble. $" 80$ The printed bibles of reformed Christendom found many quasiritualised uses that demonstrate the impossibility of distinguishing reverence for the Holy 
Text from reverence for the Holy Book as a devotional object. ${ }^{81}$ Offering an encounter with the print, shape and image of Christ, invited an understanding of the holy book as an embodied presence, as though the printed bible were a material metonym through which His presence might be redeemed. At the same time the language acknowledges the visuality of contemporary bible readers' experience. Woodcut illustrations had figured in the Geneva Bible (1560) and Archbishop Parker, who oversaw the Seconde Tome of Homelyes, was also responsible for production of the Bishops Bible (1568), heavily illustrated with designs from Virgil Solis that had served for both Catholic and Lutheran bibles on the continent evidencing in the face of objections his strong belief in "the power of imagery to enhance the understanding of holy writ.". ${ }^{82}$ Dissemination of the Erasmian call to the study of scripture is thus far from heralding an abstracted conception of the word among Reformed readers.

The integral importance of material form and visual appearance emerges forcefully in Erasmus' Exhortation to Study of the Gospel, written for the Paraphrases of Matthew (1522), later prefaced to the collected Paraphrases (1524) and translated into English by Robert Wyer in 1534. Erasmus here revisited the themes of the Paraclesis:

as a holy and deuout scoler of Christ, let hym folow hym by all his steppes, where soeuer he go. Let hym marke and take hede what he dothe, what he speaketh, let hym consydre serche and labour for the perceyuynge of eche thynge. ${ }^{83}$

If Erasmus' translation of Christ's footprints into a capacious metaphor might seem to accommodate more performative, ritualised forms of devotion, rigorous textual enquiry remains at the heart of his programme as Tyndale would recognise in citing this work, along 
with the Paraclesis, as the key texts justifying translation and study of scripture. ${ }^{84}$ The exhortation to active readership encompasses an attention to the materiality of the text that is inscribed within Erasmus's designation of Christ's footprints, both here and in the Paraclesis, by the term vestigiarum from which derives the verb investigare, root of the English investigate. ${ }^{85}$ As the humanist pedagogue, Nicholas Udall (1504-56), later chief translator of Erasmus' Paraphrases, explains in glossing a line from Plautus:

Inuestigare est \{per\} uestigia inuenire, To finde out by the foote, by the steppes, or by the trace and trede of the feete, as they that hunte $\&$ trace the wylde beastes and folowe theym by the foote, and by the trace finde theym out, and (by a metaphore therof taken) it is to finde out any thinge by diligent enserching. ${ }^{86}$

The associations of investigation gathered here are integral to Erasmus' rewriting of the Paraclesis image - indeed Erasmus' Latin playfully deploys cognates for both Christ's "steppes" (per omnia uestigia) and the injunction to "serche" (uestiget). ${ }^{87}$ Erasmus was of course highly attentive to the material presentation of his works and he concludes with a characteristically self-reflexive gesture to the printed page: "These thynges I haue put unto my boke," he confided to his "good reder," "because the prynter complayned, that oneles I so dyd, certayn pagynes \& leues wolde be voyde." 88 For all the rhetorical humility, Erasmus' consciousness of the need to supply "maner of profet" reflects his investment in the active reader, engaged in careful scrutiny of the reading matter supplied in the printed page. ${ }^{89}$

\section{Reading the Material Trace in Print: Edmund Spenser and the Investigative Reader}

Conceptualising textual study as a process of following Christ "by all his steppes" configures reading as the pursuit of material traces across the page, a fraught process in a time of 
representational crisis where seeking out the true presence of God was at the heart of confessional conflict, from the disputed status of the Eucharist to the power of the relic. In a climate of religious contestation and amid competing claims, the discerning active reader needed to be skilled in "find[ing] out by the foote," and not merely a follower. A relevant scriptural precedent existed in Daniel 14, where the prophet exposes the idol Bel. To challenge faith in Bel's nightly consumption of food offerings, Daniel scatters ashes onto the Temple floor before the doors are sealed. The next morning he discovers to the Emperor Cyrus the footprints in the ashes that lead to the secret entrance used by Bel's Priests to carry away the offerings. Grouped with the Apocrypha by Reformers but nevertheless printed with every English bible of the period, the story features in an important set of designs by Maartin van Heemskerck (1498-1574). Engraved by Theodore Galle in 1565, the prints evoke the contemporary agitation over idolatry that would culminate in an intense outbreak of imagebreaking in the Netherlands. An observant Catholic, Heemskerck was nevertheless influenced by Humanist thought, and his work circulated beyond religiously conservative consumers with designs open to reformist interpretations: noticeably, the false clerics of the $\mathrm{Bel}$ and the Dragon series are tonsured like contemporary monks. ${ }^{90}$ The sequence of images celebrate a sceptical detective procedure through which Daniel brings to light what is hidden from view. The image of the prophet discovering the priests' footprints to the Emperor (fig. 11) is the immediate precedent to the destruction of the idol. The effect of the foot's fragile impression in ash is achieved by subtle effacing of the copperplate in a way that enhances appreciation of the prophet's arts of detection. ${ }^{91}$ Van Heemskerck's prints reached a wide market and the series' appeal to reformed tastes is seen in its immediate influence on artistic production in England of the late 1560s. ${ }^{92}$ The theme was taken up shortly afterwards in the ballad Daniels Siftyng in these our dayes, aptly applyed to the true Preachers of the Gospell (fig. 12) which survives in a 1572 copy published by the popular printer Richard Jones (fl. 
1564-1613). In this overtly didactic work footprints are the medium through which man's life is made subject to divine detection as Old Testament examples of errors exposed and punished, are set alongside faults in the commonweal requiring reformationy. "Gods booke this Seeve is, that they in hand take,/ And his word the Ashes, there out for to shake/... Who so in these Ashes, now treadeth awrye/ Their steps shal be well knowne: to God \& mans eye." ${ }^{93}$ The image of the word of god in the form of sprinkled ashes that promise to publish false steps, draws attention to the layout of the ballad and the distribution of ink on the page. Printed in black-letter with a simple double border containing two evenly set columns of text, and a tiny floral device symmetrically placed on either side of the colophon, the restraint in decoration contrasts with Jones' other extant broadsides that are characterised by heavy, often discontinuous ornamentation. ${ }^{94}$ The careful order in the design of the broadside reaffirms the association of scriptural study with the materiality of its physical form.

Daniels Siftyng, like the observations in Seconde Tome of Homelyes, speak to a context in which the printed page was understood to inhabit a material form and deliver a visual impression. The printed word was conceived both in dialogue with, and as a constituent in a culture of visual representation. Sir John Harington's well-known comments on book illustration in the Preface to Orlando Furioso (1591) identify Parker's Bishop's Bible (1568) among a series of publication projects from that historical moment that brought the art of woodcut book illustration in England to new heights. Along with Foxe's Acts and Monuments (1563, but expanded with more than twice as many woodcuts in its landmark second edition 1570), George Baker's lavishly illustrated translation from Conrad Gesner The newe iewell of health (1576), and the first edition of Holinshed's Chronicles (1577), Harrington references "the book of hauking and hunting", an elaborate co-production printed in 1575 by Henry Bynneman (c.1542-1583) for Christopher Barker combining The Book of Faulconrie or 
Hauking with The Noble Arte of Venerie. ${ }^{95}$ Each title was a work of translation by a poet, the former compiled by George Turbervile (1543-1597?) from several sources, the latter George Gascoigne's translation of La Vénérie (1561), a celebrated French hunting treatise by Jacques du Fouilloux. ${ }^{96}$ Like many such printing projects it made use of original woodblocks from a continental edition, supplementing them with some specially produced woodcuts of Elizabeth that translate the locus of hunting into a Tudor context. ${ }^{97}$

As an over-determined object for the reader's consumption, Gascoigne's title offers particular insights into the intersection of the verbal, visual and material arts of reading: a single opening (fig. 13) features three different typefaces as well as elaborate initials, ornamental brackets, and a seemingly confused hierarchy of captions, running headers, section titles and chapter headings all competing for attention alongside the woodcut image. If setting of the pages tends towards the excessive, so does the printing off: the heavily inked woodcut and type are clearly visible from the reverse in several of the copies examined for this study, with a number of offset images from the woodblocks adding further effects to the heavily freighted page. Paper "remembers its ordeal at the press," according to McLeod's rumination on the presence of information additional to a copy-text, and in The Noble Arte of Venerie those memories persistently impinge on the reader's experience to make the effects of the printing process visible. ${ }^{98}$ Such effects are of particular significance in the account of tracking, the very art evoked by Erasmus in his account of the scholarly Christian reader. Tracking, it should be noted, is not a basic form of knowledge, but one characterized, as Carlo Ginzburg observes, "by the ability to construct from apparently insignificant experimental data a complex reality that could not be experienced directly."99 The methodology of "venatic deduction" was widely invoked in the period as a metaphor for scientific enquiry. ${ }^{100}$ In the wake of reformist representations of the scholar-tracker, Gascoigne's art of tracking is self- 
consciously constructed as an art of reading. His detailed descriptions highlight the evaluative and reflective processes involved in tracking each animal in the hunter's compendious bestiary. Attending to the environment (the season, weather and habitat), the tracker's inspection must encompass observation of the depth, distance and sequence as well as the precise composition of each mark. Interpreting this reading matter with the "knowledge" and “judgement” cited as principal pre-requisites of skilful tracking, Gascoigne's huntsman is able to construct a remarkably specific history of the animal's passage covering not only its age, sex, size and condition but much of its backstory, even down to its familiarity with the immediate environment. ${ }^{101}$ The process is illustrated on the page with a woodcut, re-used from La Vénérie (fig. 14), depicting a huntsman bending over three marks that represent the print, or slot, of the hart. To the right, above the farthest slot, is shown a blemish, the broken off, or plashed, bough - an annotative practice through which the huntsman marks the track for future reference of both himself and his party. However, the presentation on the page of this art of reading the traces is disrupted by surplus effects of the press. The hunter's finger pointing towards the slot is intercepted by the imprint of bleedthrough type from the verso, coming to rest on the inverted impression of iudgement. Further inspection of the image reveals that what looks like hatching is distinctly legible: the Huntsman emerges from examination of the ground immediately above the right-hand slot, while the bark of the tree behind is layered with inscriptions that bleed through from the reverse.

Such effects are not likely to be the result of careful design, but nor are they unforeseeable elements in the landscape of the printed page. Gascoigne had conducted experiments with poetic imprinting and the arts of hunting in A Hundreth Sundrie Flowers (1573), his artificial imitation of literary miscellaneity - later rebranded as The Poesies of George Gascoigne. The volume had included 'Gascoignes wodmanship' the signature work addressed to Lord Grey 
that took his failure to hit the mark while hunting with his patron as an occasion to expound his missing of opportunity more broadly. ${ }^{102}$ The poem's litany of disappointment is interrupted at the conclusion when Gascoigne brings the target deer suddenly into focus. In a striking intervention in his own poem heightened by the use of deictic markers and metrical effects, the poetic object appears at the intersection of the scene of writing and the scene of reading, on the printed page.

Let me imagine in this worthlesse verse:

If right before mee, at my standings foote

There stoode a Doe. And I shoulde strike hir deade, ${ }^{103}$

Bringing into play a familiar contemporary pun on poetic feet, the "foote" of Gascoigne's standing is aligned in stress with the accentuated doe and its own poised moment of standing. The coup de grâce is to make the deer's imagined sacrifice into an interpretive crux. Expounding the different senses that might be alleged, Gascoigne's poetic persona proposes the deer's radical translation into a moral emblem, becoming the instrument through which he purposes redemption in the eyes of his Lord, but this conclusion is again thrown in doubt by the poem's final self-dismissal as "a tedious tale in rime, but little reason." Gascoigne's vexing of the deer as a vehicle of meaning and an object of interpretation on the page inform his work on the Noble Arte of Venerie. Sufficiently versed in the practices of the printshop and the poetics of the page to engage in complex interplay, Gascoigne knew the potential for the cutaways of the woodcut block and text-less areas of the typeset page to play host to printing matter. Viewed from the perspective of reader experience, these marks are part of the opportunities for meaning presented by an elaborately contingent printing process for a readership whose careful investigation is enlisted by the author. Gascoigne's instruction in the art of reading the slot of the hart begins by announcing, immediately beneath the woodcut, "Old Hartes leaue commonly the blemishes and tokens that follow..."104 The 
language is deliberately overdetermined - it is Gascoigne who introduces the contrast of tokens and blemishes to describe the interpretive matter with which the would-be huntsman is confronted. ${ }^{105}$ The context seems to invite application to the excess of marks left behind on the page that confront the investigative reader. These interventions of the press (or printerventions), produce a surplus that might be dismissed as a kind of blemish - a printing error that obscures the clarity of meaning - or accorded significance as tokens worthy of pursuit. The tendency in literary interpretation to privilege intention in design might recommend the former, and such traces have often been suppressed by past conservation techniques or reproductive technologies that flatten or clean up the image. ${ }^{106}$ Yet a Derridean cultural graphology would suggest the need "to think about writing not as something written and waiting to be deciphered on the face of the world... but as process that is activated 'idiomatically' (that is, uniquely according to local conditions) at each of the moments and places where it may be said to occur."107 To filter out this content from readings of the page is then to seek to deny the impact of print itself: since these marks are an integral product of the mechanized process of iteration and hence the material from which literary meaning is customarily construed. For Derrida, such integrity should not be equated to plenitude. The trace is after all one of the key terms he would deploy to subvert the metaphysics of presence - "the trace is in fact the absolute origin of sense in general. Which amounts to saying that there is no absolute origin of sense in general" - and to redirect attention to the object and effects of the system of writing itself. ${ }^{108}$ In Gascoigne the effect of the instruction in tracking is to problematise the reader's relationship to the printed matter on view. Excluding these traces from the reading experience then, means turning away from the contingent materiality of the early modern page to which contemporary readers were especially attuned, and which Gascoigne calls into play in an account of tracking the hart, that is knowingly, if playfully, constructed as an art of reading. 
Where Gascoigne's Noble Arte of Venerie opens the possibility of harnessing rich material reading strategies to the printed page, a fuller realisation of that potential is found in the work of Edmund Spenser, whose interest in developing and challenging a properly investigative reader is informed by the accumulated culture of the foot in print. Like Gascoigne, with whose work he was familiar and with whom he shared both a printer and patron, Spenser's early ventures in print show his connections with continental book production and the use of woodcut illustration. ${ }^{109}$ His first publication had been as the teenage translator of works by Petrarch (via Marot) and du Bellay for the English edition of Jan van der Noot's Theatre for Worldlings (1569), a work of Protestant commentary urging Elizabeth's intervention in the Low Countries also issued in French, Dutch and German. Spenser's epigrams and sonnets for the octavo volume printed by Henry Bynneman were illustrated with a series of esoteric woodcuts that appeared first in the English edition. ${ }^{110}$ The format has evident continuities with Spenser's subsequent publications, and particularly The Shepheardes Calender (1579) which would feature specially commissioned woodcuts, modelled on those of Sansovino's Arcadia (1571), integrated into a carefully structured rhetoric of the page. ${ }^{111}$ Spenser's pastorals are framed by the scholarly apparatus of E.K.'s introductory letter and glosses that serve to establish their status as complex works both worthy of and demanding study. ${ }^{112}$ The effect is heightened by the display of co-ordinated typographic versatility, deploying italic for the argument of each month, black-letter for the verses themselves and roman for the glosses as well as proper names. ${ }^{113}$ The combination of typographic design, woodcut illustration and the rhetorical framework of annotation engages in the conspicuous construction of a reading practice, yet the elaborate material and rhetorical frameworks that solicit the reader's attention make visible a tension also found in the Reformed bibles of the period in the often uneasy mediation, already present in Erasmus's Paraclesis, between claims for the immediate 
accessibility of the text and a simultaneous acknowledgement of its strangeness. ${ }^{114}$ As the fraught critical history of The Shepheardes Calender and its glosses makes clear, the multiple framings of Spenser's poetry do not assure a unified reading but operate in tension, as much to provoke as satisfy the reader, the notorious unreliability of EK opening a space between the hermeneutic structures furnished by the printed work and the interpretive process itself. ${ }^{115}$

If the dense paratextual framework of the The Shepheardes Calender and its heavilyfreighted page are structured to impede a too-easy progress on the part of the reader, one of the challenges of reading for the material trace in Spenser's work is to know how to connect this complex design with the sparse aesthetic of his later publications. The 1590 Faerie Queene, with its uninked margins and lack of ornament would appear to represent a radical change in approach to the page - although in the light of recorded readers' marks, it has been suggested that such territory might be seen as an invitation to readers to supply their own ink and become part of a work that always anticipated annotation. ${ }^{116}$ This was the first of Spenser's works to be published by William Ponsonby, thereafter the principal figure overseeing production of his works during Spenser's lifetime, and its new aesthetic seems to have been designed as a self-conscious typecasting of English high literary production, in coordination with the printing of Sidney's Arcadia (1590) with which it shared both format and typeface, marking a landmark shift away from black-letter for vernacular literary works. ${ }^{117}$ Where the humanist apparatus of Spenser's pastorals problematized the localised speech dialects and the popular traditions of almanac that The Shepheardes Calender itself called into play, the roman typography and restrained appearance on the page of the 1590 Faerie Queene present a striking and potentially disjunctive aesthetic for an archaicising allegorical epic in the vernacular. ${ }^{118}$ Extended analysis of Spenser's epic poem is beyond the scope of this essay, but it is important to note that the Faerie Queene is both informed by a 
typographical imagination, and concerned with challenging an active readership. These issues coalesce in the celebrated Proem to Book II, where Spenser explicitly addresses interpretive strategies via the art of hunting. Tackling the questing after Faery Land of the (male-gendered) reader, the Proem announces:

Of faery lond yet if he more inquire

By certein signes here sett in sondrie place

He may it fynd; ne let him then admyre

But yield his sence to bee too blunt and bace

That no'te without an hound fine footing trace ${ }^{119}$

The figuring of a reader dependent upon a dog to help him find his feet in the poem presents a cautionary image of a base, sensory pursuit without skill or reflection and is in keeping with the many instances where protagonists are led astray - none more obvious than the errant pathway "with footing worne, and leading inward farr" that ensnares the protagonists of Book I in the Wandering Wood. ${ }^{120}$ However, such blind following of signs is far removed from the discerning art concerned with investigation - just as the poet would signal Book IV's artful continuation of Chaucer in both matter and metre by acknowledging "I followe here the footing of thy feete." ${ }^{\prime 21}$ The Proem critique is characteristic of Spenser's method of scrutinising epistemological process, so that habits of seeing and knowing are instead "posed as problems and questions for both reader and protagonist to resolve."122 The imagery and metaphors of hunting are, as Catherine Bates points out "omnipresent" in the Faerie Queene, but the vexed concern with footing, traces and tracking in the poem signals Spenser's interest in an investigative reader who brings both knowledge and judgement into the evaluation of print. $^{123}$ 
Spenser's conception of an investigative reader finds its fullest realisation in the Amoretti (1595) where the author instrumentalises a specifically material art of reading the traces. The rhetorical concern with materiality is announced in the opening conceit of "eroticised textual exchange" through which male poets customarily negotiated their entrance into print. ${ }^{124}$ Sonnet 1 presents the poems in the hands of the mistress, licensing an investigation of the scene of reading that depicts the poetry before the mistress's "lamping eyes" as a conjunction of leaves, lines and rhymes, signifying the integral union of material, visual and textual elements. Spenser's corporeal fiction of text production ("Written with tears in heart's close bleeding book") presents the book from the outset as overwrought, exceeding the everyday properties of textuality. The image of the bleeding heart equates the sufferings of the lover with those of Christ, an uneasy parallel which the poet would later develop across the Foure Hymes (1596) but whose tensions are here invested in the volume itself. ${ }^{125}$ Rhetorical concerns overlap with the material. The form of the Amoretti octavo, printed for Ponsonby by Peter Short, followed the lead set in successive editions of Samuel Daniel's Delia, not only adopting the use of reglets in the spaced setting of a single sonnet to the page, but closely imitating ornamental headers and tailpieces, and the style of sonnet numbering. ${ }^{126}$ This influential framework informed the imagination of contemporary poets who might now, as Juliet Fleming has suggested, "visualise fourteen lines of Roman type, set alone on the page, within head- and tail-borders." 127 In the case of Spenser, although Ponsonby describes the volume as published in the author's absence, the conventionality of the framework, the close relationship he enjoyed with his printer and his longstanding interest in print production all argue for Spenser designing his sonnets with printed effects in mind. ${ }^{128}$ Such attention is certainly in keeping with the structural coherence of a work that seeks to map the atypical progression from sonnet courtship towards marriage onto a calendrical progression through 
the liturgy of the passion organised around the paired Ash Wednesday (22) and Easter Sunday (68) sonnets, separated by 46 poems equating to the daily services over Lent, with twin sequences of 21 sonnets either side. ${ }^{129}$ The biographical and calendrical allusions that equate the sequence with the 1594 courtship of Spenser and his second wife Elizabeth Boyle demonstrate the integrity of the volume as a whole and the place of both the Anacreontics and Epithalamion within the overall design, but it is the Amoretti that will be the focus of attention here. ${ }^{130}$

Spenser's rich engagement with mis-en-page in the Amoretti is demonstrated by his use of facing pages for sonnets with mirrored concerns, such as the pairing of sonnets 74 and 75 that places the erasure of the beloved's name written in the strand, against the triple affirmation of Elizabeth as mother, queen and lover. ${ }^{131}$ Where sonnet 75 transposes the impermanence of earthly writing into a promise of poetry's eternizing power, it is sonnet 74, with its typographically evocative celebration of those "most happy letters fram'd by skillfull trade," that reproduces in print the name that eludes sonnet 75 . The extent of typographic consciousness informing the volume is highlighted by the repetition of sonnet 35 in slightly modified form as sonnet 83 (fig. 15, fig. 16). Once critically lamented, the recognition of a structural progression from courtship to betrothal (secured in sonnet 67) gives meaning to a repetition that "dramatizes the discomforts of the lover as fiancé," yet the recurrence of the poem also has implications for the experience of a reader invited to act effectively as corrector and collate the two printed copies. ${ }^{132}$ The act of investigating the repetition is itself thematised in the poem's evocation of Narcissus, enamoured of his own reflection. In the Ovidian source, the self-desire of Narcissus is the result of a lack of self-knowledge, giving the myth a particular Neo-Platonic significance, and adding a level of critique to the selfabsorption of Spenser's obsessive lover. ${ }^{133}$ Ovid also took the occasion to de-stabilise the 
relation of original to copy: beguiled by the image in the water he fails to recognise, Narcissus becomes, in Golding's translation, “Astraughted like an ymage made of Marble stone." "134 Spenser expands on Ovid's precedent to present the reader with two mirroring poetic constructions for inspection. In comparing Spenser's sonnet 35 and its reflection critics have pointed to a single substantive difference between the two in the switch from "hauing" to "seeing" in line 6 , a change that accentuates the frustrated desire of the betrothed lover not yet in possession of his fiancée. There is also, however, a significant typographic difference to be found in the contrasting use of italic and roman type for the printing of Narcissus' name. That Spenser attached significance to the use of the italic typeface is suggested by his memorialisation of its first exponent, the Venetian printer Aldus Martinus, with the character of Aladine, son of Aldus, in the continuation of the Faerie Queene, shortly to be printed at the same press. ${ }^{135}$ To any reader actively comparing the two pages, the shift in typeface is the most immediately detectible difference and its occurrence in the textual act of nomination foregrounds the distorting effect of reproduction: the printed Narcissus is not identical to his posited reflection, a conclusion that serves to underline the vanity of his desire. The dissimilarity is unsettling for the reader since Narcissus functions in the poems specifically as a figure of likeness; a simile for the lover whose dissatisfied eyes lead him to pursue the shadow rather than the true object. The instability of the two printed Narcissae, contrasting iterations with neither secure in the status of original, thus seems to figure for the reader the difficulty of discerning true presence. In a sceptical counterpoint to Dürer's thematization of the acheiropoietos in the woodcut images of the Sudarium, Spenser's conjunction of dissonant Narcissae, with their different slants, is an intervention of the press that serves to sharpen the critical faculties of the investigative reader. 
Just as Dürer's Small Passion had combined the thematization of divinely sanctioned reproduction with a co-opting of the medium in its sequence of Sudarium and Ascension woodcuts, so Spenser brought into play a materialised conception of printing and book production providing his most pointed illustration of how a properly investigative art of reading extends the interpretive challenge of printed poetry not in reflections of Narcissus, but in the material meditation on footprints that dominates Amoretti 78. In this sonnet, the poet returns to the hunting theme that is such a marked feature of his work. Sonnet 67 , his adaptation after Wyatt from Petrarch's Rime 190, had presented the submission of the mistress to marriage through the free submission of the deer to the huntsman. When the deer imagery recurs in 78 , the poet reworks the conventions of the amatory hunt and in an echo of Horace Ode I.23, compares the lover to a fawn bereft at having lost its hind. Experiencing the absence of his betrothed, the lover pursues the traces of her presence in fields "with her late footing signed." The lover's following of the mistress by her footprints embedded in the environment is however unsuccessful, like Narcissus his eyes feed him with "fancies vain" rather than a glimpse of his "true object," and the absence, he learns, can only be recuperated through inward contemplation. The play on the beloved's footprints as a form of signing recalls the transposed scene of writing in sonnet 75 where the author's hand twice attempted the inscription of her name upon the strand. Both strand and field are deliberately disjunctive writing sites, more familiar as scenes of printing with the foot than writing with the hand and just as the handiwork is subject to erasure in sonnet 75 , so in 78 the hand's function as signing instrument is displaced by the foot. The conjuring of the printing foot here evokes its twin in the press, drawing attention to the realisation of the poem on the printed page (fig. 17) where Spenser's design emerges most fully. 
The poem is rendered as an object of investigation realised in concrete terms through a series of repetitions which function as footprints on the printed page. In lines 1 and 3 repetitions of "place" and "where" respectively follow heel-to-toe the linear direction. When the poet turns to describing directly the footprints in lines 5-6, however, the movement becomes a double track traversing the line: "I seeke" and "with her late" mirror each other in a slanting progress. Across lines 7-8 the same staggered movement in sequence occurs, now tripled in the repetitions of "yet," "field," and "bowre." In this quatrain there are even further repetitions ("field" 1.5 , "bowre" 1.6 ) as though the poetic line here ran across preceding prints. The impression of a muddy field overlaid with tracks is exacerbated by the curious double mark at line 7, between "nor" and "in", that exposes the topographic effects of the press (fig. 18): the dual impact of printing's deformations of the dampened paper from both sides have here wrought a crater still visible to the naked eye more than four hundred years after it dried, leaving behind the blurred inky mark where type and spacing matter slipped in the damp conditions to leave the trace of a misstep. In the next quatrain there is an abrupt shift as the lover acknowledges the tendency of his eyes to reward him only with vanity; here a single repetition spanning three lines ("when") is an overextension of the device, stalling the sense of movement. The footprints return, however, near the ends of the concluding couplet, where the lover's desire to see "her selfe" in line 13, finds its match as the object of his thoughts in the line below. Repetition is of course a staple of poetry, but the intent to reproduce the effect of footprints on the page is indicated by the typographic care over the poem's setting: in the printing of a work otherwise displaying the characteristic orthographical flexibility of the period, none of the twelve non-pronouns repeated in the poem have any spelling variation. This can be contrasted with the facing sonnet (79), of whose two repeated words one is variable, while in the reflected sonnet discussed above (35/83), there are six words whose spelling differs across the two versions (their, pain, complain, poor, faith, loathe). In 
contrast to the disjunction of Narcissus/Narcissus, where the reader is confronted with material differences, the setting of sonnet 78 shapes a precise pattern of repetition that invites the reader to follow the material trace in construing the poem.

As one might expect given Spenser's concerns over mere following, however, the reader's course is not quite so smooth. The use of rhyme as repetition has not been noted above although the coincidence of orthography with homophony ensures rhymed endings are often echoed in type, but at the end of the fifth and seventh lines Spenser pairs 'synd' and 'fynd' not only in rhyme and in metrical planting of the poetic foot, but as false visual simulacra imprinted on the page. The long $s$ of Peter Short's roman typeface, with its leftward spur, is easily confused with the $f$, whose cross-bar is susceptible to under-inking. Sixteenth-century readers of print, even those not yet habituated to roman typefaces, were less likely to stumble in the construction than today's, but the properly investigative reader is primed to go further in identifying the play of false resemblance as illustrating on the page the risk of misinterpreting the imprinted sign.

The material trace of the foot's print is then a deliberate textual crux, displaying the conjunction of sign and false sign that takes on particular significance from the Amoretti's engagement with Christian symbolism. Anne Lake Prescott has shown how the imagery of sonnets 67-70, is indebted to a rich intertextual web paralleled in Marguerite de Navarre's Chansons Spirituelles (1547) where deer-related religious imagery drawing on the psalms, the Book of Common Prayer, and the Sarum rite, associates the deer's submission with Christ's self-sacrifice - a link Gascoigne had also suggested in 'wodmanship. ${ }^{136}$ While noting the shifting nature of Biblical deer, liable to change sex and signification across translations and retellings, Prescott's analysis links the imagery to the calendrical sequence 
from Easter Saturday (67) through to the structurally key Easter sonnet that follows it. But while the identification of the Lenten sonnets (22-68) has been widely accepted few have found precise liturgical coordinates in the Amoretti's remaining sonnets beyond W. C. Johnson, who assumes an unbroken daily progression through the whole Amoretti cycle, and Kenneth Larsen, whose detailed schema identifies a temporal skip in the sequence after sonnet 75. ${ }^{137}$ Larsen's calendrical jump leads him to identify sonnet 78 with 5 May, Rogation Sunday, detecting correspondences with the set psalms, and readings noted in the Book of Common Prayer - a re-alignment that also provides a direct connection to the rite of beating the bounds, the annual parish perambulation discussed in the introduction that survived the reformation of the ritual calendar as an assertion of Christian community (and property rights) enacted by retracing the footsteps of community elders. ${ }^{138}$ Many of the associations Larsen evokes apply as well within a more general Christological chronology where the final sonnets of absence (69-89), equate to a post-Resurrection context via the thematic resonances of the deer-as-Christ. In particular the sonnet's concern with the desire to recover presence through pursuit of the material sign draws upon the contested meanings of Christ's footprints so strongly associated in the contemporary imagination with the Ascension. Spenser's poem rehearses the temporality of His presence through the distinctly muddy footprints in the field. In doing so the sonnet evokes the history of Christ's footprints as object of veneration (whether in stone, or in print), bringing to bear the careful investigative approach that Spenser demanded of his readers. As Erasmus had sought to redirect devotion from the footprint relic to the printed word so Spenser trains his readers' attentions on the material trace in order to engage them in a discerning piety that is able to forego "idly" pursing an idolatrous devotion to the sign and finds instead its true object through internal contemplation. Having investigated the footprints of the poem, Spenser's reader finds them lacking in presence - a conclusion reinforced by the encounter on the 
fifteenth line with the catchword 'Lackyng' bleeding through from the verso in inverted form. Concluding the poem's interrogation of similitudes, this final ghostly intervention of the press marks the impression of vacated presence within the poem.

Spenser's sonnet is thus indicative of the rich metaphorics attaching to the imprint of the foot in the early modern period. His exploration of the material environment of the page is founded on the equation of the printing foot with printing press. The pursuit of that analogy in the poem, applied to the departed presence of the deer as lover/Christ, builds upon the printed imagery of the Ascension and the contested status of Christ's footprints as object of devotion and subject of investigation. The marking of the page that encompasses both signs of the foot and false signs, speaks to the potential for misreading the material presence of Christ in the sign. In so doing Spenser's deployment of the foot in print touches upon the central interpretive crux of the Reformation: the Eucharistic controversy itself. Spenser's poem thus stands as a demonstration of the extraordinary resonance of the footprint within the cultural imagination of early modern England, and of the critical importance attached to the work of a properly investigative reader, attentive to and sophisticated in, the interrogation of the printed page. The discovery of Spenser's footprints reveals the importance of attending to the material trace within the culture of print, and the need for critics to engage with the complex interactions of visual, verbal and physical elements in the dynamic interpretive environment of the early modern page. Writers such as Gascoigne and Spenser embraced and made space for the effects of the press (from the super- to the intra-textual) even as they cautioned readers against a credulous devotion towards each and every mark. The challenge which they posed to the early modern reader is one which the contemporary critic is also bound to take up. Investigation of the renaissance footprint leads in more directions than can be fully described here, from the courses of the metrical foot, to the dancing steps of the body 
in time as well as space. In opening a way to interrogate the material trace in the culture of print, it is to be hoped that others will follow in redressing the imbalance in literary responses to the foot, and that like Spenser's Mount Acidale, this critical pathway may play host to "many feete fast thumping th'hollow ground."139 


\section{Captions}

Figure 1. Woodcut colophon of Jodocus Badius from titlepage of John Major, Historia Maioris Britanniae, tam Angliae quam Scotiae (Paris, 1521). (C) University of Aberdeen. AUL Pi GY 9(41) Maj.

Figure 2. Arma Christi with bloody footprints, painted ivory, c.1330-40. (C) Victoria and Albert Museum, London. Museum no. 11-1872.

Figure 3. Mass of Saint Gregory with instruments of the Passion, fifteenth-century single-leaf woodcut. (C) Kupfestichkabinett. Staatliche Museen zu Berlin, Inv. Nr. 200-1.

Figure 4. Albrecht Dürer. Christ Bearing the Cross from the Small Passion. 1511. Woodcut print. Metropolitan Museum of Art.

Figure 5. Albrecht Dürer. The Sudarium from the Small Passion. 1511. Woodcut print. Metropolitan Museum of Art

Figure 6. The Ascension of Christ from the Small Passion. 1511. Woodcut print. Metropolitan Museum of Art

Figure 7. The Ascension, woodcut from Jacobus de Voraigne, Legenda Aurea trans Caxton. London, 1487, fol. 23 $3^{\mathrm{r}}$. (C) University of Aberdeen. AUL Inc 225.

Figure 8. Albrecht Dürer The Ascension of Christ, woodcut block. 1511. B M PD 1839,0608.3.50 @ The Trustees of the British Museum.

Figure 9. After Virgil Solis, Ascension of Christ from unnamed Passional. Woodcut print, c.1552. B M PD 1874.0711.1942 @ The Trustees of the British Museum.

Figure 10. Lucas Cranach, Ascension of Christ with Fall of the Anti-Christ from Passional Christi und Anti-Christi. Nuremberg, 1521. Royal Library, Denmark.

Figure 11. Maerten van Heemskerck, Daniel discovering the footprints to Cyrus from Daniel, Bel and the Dragon series, engraved by T. van Galle, 1565. BMPD D,5.93. () The Trustees of the British Museum. 
Figure 12. Daniels Siftyng in these our dayes, aptly applyed to the true Preachers of the Gospell (London, Richard Jones, 1572). The Huntington Library, San Marino, California. HL18288.

Figure 13. [George Gascoigne], The Noble Art of Venerye (1575), p.60-61. (C) University of Aberdeen. AUL Pi79925Tur

Figure 14. [George Gascoigne], The Noble Art of Venerye (1575), p.62-63. (C) University of Aberdeen.

Figure 15. Sonnet 35 from Edmund Spenser, Amoretti and Epithalamion (London, 1595) (C) Special Collections, University of Edinburgh. EUL De.2/1.51.

Figure 16. Sonnet 83 from Spenser, Amoretti. (C) Special Collections, University of Edinburgh.

Figure 17. Sonnet 78 from Spenser, Amoretti. (C) Special Collections, University of Edinburgh.

Figure 18. Detail of Sonnet 78 from Spenser, Amoretti. (C) Special Collections, University of Edinburgh. 


\section{Bibliography}

Anderson, Christine and Charles Talbot. From a Mighty Fortress: Prints, Drawings, and Books in the Age of Luther, 1483-1546. Detroit: Detroit Institute of Arts, 1983.

Arnold, Richard. In this booke is conteyned the names of ye baylifs custos mairs and sherefs of the cite of londo[n] from the tyme of king richard the furst. London, 1503.

Ashton N, SG Lewis, I De Groote, SM Duffy, M Bates and R Bates, "Hominin Footprints from Early Pleistocene Deposits at Happisburgh, UK.” PLoS ONE 9.2 (2014): e88329. doi:10.1371/journal.pone.0088329.

Areford, David S. "Multiplying the sacred; The Fifteenth-Century Woodcut as Reproduction, Surrogate, Simulation.” In The Woodcut in Fifteenth-Century Europe, ed. Peter Parshall, 11954. Washington, D.C.: National Gallery of Art, 2009.

Ariosto, Ludovico. Orlando Furioso in English heroical verse, by Iohn Haringto[n]. London, 1591. Aston, Margaret. "Symbols of Conversion: Properties of the Page in Reformation England.” In Printed Images In Early Modern Britain: Essays in Interpretation ed. Michael Hunter, 23-42. Farnham: Ashgate, 2010.

Aston, Margaret. "The Bishops' Bible Illustrations.” In The Church and the Arts, ed. Diana Wood. Studies in Church History 28 (1995), 267-85.

Aston, Margaret. The King's Bedpost: Reformation and Iconography in a Tudor Group Portrait. Cambridge: Cambridge University Press, 1993.

Austen, Gillian. George Gascoigne. Woodbridge: D.S. Brewer, 2008.

Bangs, Jeremy D. "Maerten ven Heemskerck's Bel and the Dragon and Iconoclasm," Renaissance Quarterly 30.1 (1977), 8-11.

Bartram, Giulia. Albrecht Dürer and his Legacy: The Graphic Work of a Renaissance Artist. London: British Museum, 2002. 
Bates, Catherine. Masculinity and the Hunt: Wyatt to Spenser. Oxford: Oxford University Press, 2013.

Bath, Michael. "Verse Form and Pictorial Space in Van der Noot's Theatre for Worldlings." In Word and Visual Imagination: Studies in the Interaction of English Literature and the Visual Arts ed. by Karl Josef Höltgein, Peter M Daly and Wolfgang Lottes, 73-105. Erlangen: Universitätsbibliothek Erlangen-Nürnberg, 1988.

Beckwith, Sarah. Christ's Body: Identity, Culture and Society in Late Medieval Writings. London: Routledge, 1996.

Belting, Hans. Likeness and Presence: A History of the Image before the Era of Art, trans. Edmund Jephcott. Chicago and London: University of Chicago Press, 1994.

Berliner, Rudolf. “Arma Christi.” Münchner Jahrbuch der bildenden Kunst 3.6 (1955), 35-152.

Blank, Paula. Broken English: Dialects and the Politics of Language in Renaissance Writing. London: Routledge, 1996.

Bland, Mark. "The Appearance of the Text in Early Modern England," Text 11 (1998), 91-154.

Bord, Janet. Footprints in Stone: Imprints of giants, heroes, holy people, devils, monsters and supernatural beings. Loughborough: Heart of Albion, 2004.

Brooks, Douglas A. “'Made all of rusty yron, ranckling sore:' The Imprint of Paternity in The Faerie Queene." In Textual Conversations in the Renaissance: Ethics, Authors, Technologies ed. Zachary Lesser and Benedict S. Robinson, 173-97. Aldershot: Ashgate, 2006.

Calhoun, Joshua. "The Word Made Flax: Cheap Bibles, Textual Corruption, and the Poetics of Paper," PMLA (2011), 327-44.

Calvin, Jean, A Very profitable treatise, MADE BY M. IHON Caluyne, declarynge what great profit might come to al christen+dome, yf there were a regester made of all Sainctes bodies and other reliques, which are aswell in Italy, as in Fraunce, Dutchland, Spaine, and other kingdomes and countreys, trans. Steuen Wythers. London, 1561. 
Campbell, Ewan. "Royal Inauguration in Dál Raita and the Stone of Destiny." In The Stone of Destiny: Artefact and Icon ed. Richard Welander, David J. Breeze and Thomas Owen Clancy, 43-60. Edinburgh: Society of Antiquaries of Scotland, 2003.

Celenza, Christopher S. 'Lorenzo Valla's Radical Philology: The 'Preface' to the Annotations to the New Testament in Context," Journal of Medieval and Early Modern Studies 42.2 (2012), $365-394$.

Cummings, Brian. The Literary Culture of the Reformation: Grammar and Grace. Oxford: Oxford University Press, 2007.

Daniels Siftyng in these our dayes, aptly applyed to the true Preachers of the Gospell. London, 1572. Davenport, Edwin. "Elizabethan England's Other Reformation of Manners," ELH 63 (1996), 25578.

Denny-Brown, Andrea and Lisa H. Cooper. "Introduction: Arma Christi: The Material Culture of the Passion”. In The Arma Christi in Medieval and Early Modern Material Culture ed. Andrea Denny-Brown and Lisa H. Cooper, 1-19. Farnham: Ashgate, 2014.

Derrida, Jacques. Of Grammatology trans. G. Spivak. Baltimore and London: Johns Hopkins, 1997. Deshman, Robert. "Another Look at the Disappearing Christ: Corporeal and Spiritual Vision in Early Medieval Images,” Art Bulletin 79 (1997), 518-546.

Desjardins, R. "Les Vestiges du Seigneur au mont des Oliviers. Un courant mystique et iconographique", Bulletin de Littérature ecclésiastique 73 (1972), 51-72.

Devereux, E.J. "The publication of the English Paraphrases of Erasmus," Bulletin of the John Rylands Library 51 (1969), 348-367.

de Grazia, Margareta. "Imprints: Shakespeare, Gutenberg and Descartes.”" In Alternative Shakespeares, vol 2, ed. Terence Hawkes, 63-94. London: Routledge, 1996. de Grazia, Margreta and Peter Stallybrass. "The Materiality of the Shakespearean Text," Shakespeare Quarterly 44 (1993), 255-83. 
du Fouilloux, Jacques. La Vénérie. Paris, 1573.

Dunlop Alexander. “The Unity of Spenser's Amoretti.” In Silent Poetry: essays in numerological analysis, ed. Alastair Fowler, 153-169. London: Routledge, 1970.

Eamon, William. "Science as a Hunt," Physis 31 (1994), 393-432.

Edwards, Calvin R. “The Narcissus Myth in Spenser's Poetry,” Studies in Philology 74 (1977), 6388.

Erasmus, Desiderius. An exhortation to the diligent studye of scripture, made by Erasmus Roterodamus. And tra[n]slated in to inglissh. An exposition in to the seventh chaptre of the first pistle to the Corinthians. Antwerp (?), 1529.

Erasmus, Desiderius, An exhortacyon to the study of readynge the Gospell Made by Erasmus of Roterdame, \& lately translated in to Englyshe. Norwich, Robert Wyer, 1534.

Erasmus, Desiderius, "Exhortatio ad studium Euangelicae lectionis.” In Epistola Nvncvpatoria ad Carolum Caesarem. Basel, 1522.

Erasmus, Desiderius, Novvm Instrumentum omne. Basel, 1516.

Erasmus, Desiderius. The Praise of Folly and Other Writings, ed and trans Robert M. Adams. New York, 1989.

Field, Richard. S. "A Fifteenth-Century Picture Panel from the Domincan Monastery of Saint Catherine in Nuremberg." In The Woodcut in Fifteenth-Century Europe, ed. Peter Parshall, 205-37. Washington, D.C.: National Gallery of Art, 2009.

Fleming, Juliet. "Changed opinion as to flowers.” In Renaissance Paratexts, ed. Helen Smith and Louise Wilson, 48-64. Cambridge: Cambridge University Press, 2011.

Fleming, Juliet. Cultural Graphology: Writing after Derrida. Chicago and London: University of Chicago Press, 2016.

Flete, John. The History of Wesminster Abbey ed. J. Armitage Robinson. Cambridge: Cambridge University Press, 1909. 
Freedberg, David. “Art and Iconcolasm, 1525-1580: The Case of the Northern Netherlands.” In Kunst voor de beeldenstorm: Noordnederlandse Kunst, 1525-1580, ed J.P. Filedt Kok, W Halsema Kubes and W. T. Kloek, 39-84. Amsterdam: Staatsuitgeverij, 1986.

Fritz, Jean-Marie. "Empreintes et vestiges dans les récits de pèlerinage: quand la pierre devient cire.” Le Moyen Age 118.1 (2012), 9-40. DOI : $\underline{10.3917 / \mathrm{rma} 181.0009}$.

Fukuda, Shohachi. "The Numerological Patterning of Amoretti and Epithalamion," Spenser Studies 9 (1988), 33-48.

Gascoigne, George. A Hundreth Sundrie Flowres ed. G. W. Pigman III. Oxford: Oxford University Press, 2000.

[Gascoigne, George]. The Noble Arte of Venerie. London, 1575.

Gaskell, Roger. "Printing House and Engraving Shop. A Mysterious Collaboration.” The Book Collector 23 (2004), 213-237.

Ginzburg, Carlo. “Clues: Roots of an Evidential Paradigm.” In Clues, Myths and the Historical Method trans J and A Tedeschi, 96-125. Baltimore: Johns Hopkins, 1980.

Goldberg, Jonathan. Writing Matter: From the Hands of the English Renaissance. Stanford: Stanford University Press, 1990

Gordon, Andrew. Writing Early Modern London: Memory, text and community. Basingstoke: Palgrave Macmillan, 2013.

Goris, J-A. and G Marlier. Albrecht Dürer: Diary of His Journey to the Netherlands, 1520-1521. New York: New York Graphic Society, 1971.

Grafton, Anthony. The Culture of Correction in Renaissance Europe. London: British Library, 2011. Grogan, Jane. Exemplary Spenser: Visual and Poetic Pedagogy in The Faerie Queene. Farnham: Ashgate, 2009.

Hadfield, Andrew. Edmund Spenser: A Life. Oxford: Oxford University Press, 2012. 
Hamburger, Jeffrey. The Visual and the Visionary: Art and Female Spirituality in Late Medieval Germany. New York: Zone Books, 1998.

Hamrick, Stephen. “'Set in portraiture’: George Gascoigne, Queen Elizabeth, and Adapting the Royal Image,” Early Modern Literary Studies 11.1 (2005) 1.1-30 <URL: http://purl.oclc.org/emls/11-1/hamrgasc.htm>.

Harrison, Terry. "Laetoli Revisited: Renewed Paleontological and Geological Investigations at Localities on the Eyasi Plateau in Northern Tanzania.” In Paleontology and Geology of Laetoli Human Evolution in Context. Volume 1, Geology, geochronology, paleoecology and paleoenvironment, 1-15. Dordrecht and New York: Springer, 2011.

Heninger, S. K., Jr. “The Typographical Layout of Spenser's Shepheardes Calender.” In Word and Visual Imagination: Studies in the Interaction of English Literature and the Visual Arts ed. Karl Josef Höltgein, Peter M Daly and Wolfgang Lottes, 33-71. Erlangen: Universitätsbibliothek Erlangen-Nürnberg, 1988.

Hindle, Steve. "Beating the Bounds of the Parish: Order, Memory and Identity in the English Local Community, c.1500-1700.” In Defining Community in Early Modern Europe, ed. M Halvorson and K. Spierling, 205-227. Aldershot: Ashgate, 2008.

Hodnett, Edward. English Woodcuts, 1480-1535. Oxford: Oxford University Press, 1973. Ingold, Tim. "Culture on the Ground: The World Perceived Through The Feet," Journal of Material Culture 9.3 (2000), 315-340.

Ingold, Tim. The Life of Lines. London: Routledge, 2015.

Ingold, Tim and Jo Lee Vergunst. "Introduction." In Ways of Walking: Ethnography and Practice on Foot, ed. Ingold and Vergunst, 1-20. Aldershot: Ashgate, 2008.

Jardine, Lisa. Erasmus, Man of Letters: The Construction of Charisma in Print. Princeton: Princeton University Press, 1993. 
Johnson, William C. "Spenser's Amoretti and the Art of the Liturgy." Studies in English Literature, 1500-1900 14.1 (1974), 47-61.

Karim Cooper, Farah. The Hand on the Shakespearean Stage: Gesture, Touch and the Spectacle of Dismemberment. London: Bloomsbury, 2016.

Kaske, Carol. "Spenser's Amoretti and Epithalamion of 1595: Structure, Genre, and Numerology," English Literary Renaissance 8.3 (1978), 271-95.

King, John N. Spenser's Poetry and the Reformation Tradition. Princeton: Princeton University Press, 1993.

Knapp, James A. “The Bastard Art: Woodcut Illustration in Sixteenth-Century England.” In Printing and Parenting in Early Modern England ed. Douglas A. Brooks, 151-172. Aldershot: Ashgate, 2005.

Koerner, Joseph Leo. The Moment of Self-Portraiture in German Renaissance Art. Chicago and London: University of Chicago Press, 1993.

Koerner, Joseph Leo. “Albrecht Dürer: A Sixteenth Century Influenza.” In Bartram, Giulia. Albrecht Dürer and his Legacy: The Graphic Work of a Renaissance Artist, 18-38. London: British Museum, 2002.

Kühnel, Bianca, Galit Noga-Banai and Hanna Vorholt, eds. Visual Constructs of Jerusalem. Turnhout: Brepols, 2014.

Landau, David and Peter Parshall. The Renaissance Print, 1470-1550. New Haven and London: Yale University Press, 1994.

Leggatt, Alice. "Walking Stories: Leaving Footprints.” In Ways of Walking: Ethnography and Practice on Foot, ed. Tim Ingold and Jo Lee Vergunst, 35-49. Aldershot: Ashgate, 2008.

Luborsky, Ruth Samson. “The Illustrations to The Shepheardes Calender,” Spenser Studies 2 (1981), 3-53. 
Luborsky, Ruth Samson. "The Illustrations to The Shepheardes Calender II," Spenser Studies 9 (1988), 249-53.

McCabe, Richard A. “Annotating Anonymity, or Putting a Gloss on The Shepheardes Calender." In Ma(r)king the Text: The Presentation of Meaning on the Literary Page ed. Joe Bray, Miriam Handley, and Anne C. Henry, 35-54. Aldershot: Ashgate, 2000.

McCabe, Richard A. "'Little booke: thy selfe present": The Politics of Presentation in The Shepheardes Calender', in Presenting Poetry: Composition, Publication, Reception ed. Howard Erskine-Hill and Richard A. McCabe, 15-40. Cambridge: Cambridge University Press, 1995.

McCanles, Michael. "The Shepheardes Calender as Document and Monument," Studies in English Literature, 1500-1900 22.1 (1982), 5-19.

McDonald, Mark P. Ferdinand Columbus: Renaissance Collector. London: British Museum, 2005. [McLeod, Randall]. “An EPILOGVE, Allegro ma troppo. Hammered, by R. McGeddon.” In Negotiating the Jacobean Printed Book, ed. Pete Langman, 136-199. Aldershot: Ashgate, 2011.

[McLeod, Randall]. "Where Angels fear to read." In Ma(r)king the Text: The presentation of meaning on the literary page, ed. Joe Bray, Miriam Hadley and Anne C. Henry, 144-192. Aldershot: Ashgate, 2000.

Mayor, Adrienne and William A. S. Sarjeant. "The folklore of footprints in stone: From classical antiquity to the present." Ichnos 8.2 (2001), 143-163.

Moshenska, Joe. Feeling Pleasures: The Sense of Touch In Renaissance England. Oxford: Oxford University Press, 2015.

Mukerji, Chandra. From Graven Images: Patterns of Modern Materialism. New York: Columbia University Press, 1983.

Munday, Anthony. The English Romayne lyfe. London, 1582. 
Nelson, William. The Poetry of Edmund Spenser: A Study. New York: Columbia University Press, 1963.

Nichols, Ann Eljenholm. "The Footprints of Christ as Arma Christi: The Evidence of Morgan B.54." In The Arma Christi in Medieval and Early Modern Material Culture ed Andrea DennyBrown, Lisa H. Cooper, 113-133. Farnham: Ashgate, 2014.

Nichols, Ann Eljenholm. “'O Vernicle': Illustrations of an Arma Chirsti Poem”. In Tributes to Kathleen L. Scott: English Medieval Manuscripts: Readers Makers and Illuminators ed Marlene Villalobos Hennessey, 138-169. Turnhout, Belgium, 2009.

Nicholson, Catherine. Uncommon Tongues: Eloquence and Eccentricity in the English Renaissance. Philadelphia: University of Pennsylvania Press, 2014.

Norton, Sir Thomas. "Prefatory letter to James Hawes, Lord Mayor of London, 1574”. British Library, Add MS, 33271, fols 28-31.

Ovid. Shakespeare's Ovid Being Arthur Golding's Translation of the Metamorphoses, ed. W. Rouse. London: De La More Press, 1904.

Parshall, Peter and Rainer Schoch with David S. Areford, Richard S Field, and Peter Schmidt. Origins of European Printmaking: Fifteenth-Century Woodcuts and Their Public. New Haven and London: Yale University Press, 2005.

Prescott, Anne Lake. "The Thirsty Deer and the Lord of Life: Some Contexts for Amoretti 67-70," Spenser Studies 6 (1985), 33-76.

Prouty, Charles and Ruth Prouty. "George Gascoigne, The Noble Arte of Venerie, and Queen Elizabeth at Kenilworth.” In Joseph Quincy Adams Memorial Studies ed. James Gilmer McManaway, 639-664. Washington DC: Folger Shakespeare Library, 1948 Renouard, Philippe. Bibliographie des Impression et des Oeuvres de Josse Badius Ascensius, Imprimeur et Humaniste, 1462-1535, 3 vols. Paris: Em. Paul, 1908. 
Rowe, Katherine. “God's handy worke." In The Body In Parts: Fantasies of Corporeality in Early Modern Europe ed. David Hillman and Carla Mazzio, 285-312. New York and London: Routledge, 1997.

Rubin, Miri, Corpus Christi: The Eucharist in Late Mediaeval Culture. Cambridge: Cambridge University Press, 1991.

Rublack, Ulinka. "Grapho-Relics: Lutheranism and the Materialization of the Word," Past and Present (2010), Supplement 5: Relics and Remains ed. Alexandra Walsham, 144-166.

Saunders, Eleanor A. “A Commentary on Iconoclasm in Several Print Series by Maarten van Heemkerch," Simiolus: Netherlands Quarterly for the History of Art 10.2 (1978-9), 59-83.

Schapiro, Meyer. “The Image of the Disappearing Christ.” Reprinted in Late Antique, Early Christian and Mediaeval Art: Selected Papers, 266-87. New York: G Brazillier, 1979.

Schiller, Gertrud. Iconography of Christian Art. 2: The Passion of Jesus Christ, trans Janet Seligman. London: Lund Humphries, 1972.

Schottus, Franciscus. Italy in its original glory, ruine, and revival being an exact survey of the whole geography and history of that famous country, trans. Edmund Warcupp. London, 1660.

Scott-Warren, Jason. "Unannotating Spenser.” In Renaissance Paratexts ed Helen Smith and Louise Wilson, 153-64. Cambridge: Cambridge University Press, 2011.

Scribner, R. W. For the Sake of the Simple Folk: Popular Propaganda for the German Reformation Oxford: Clarendon Press, 1994.

Shepard, Alexandra. Meanings of Manhood in Early Modern England. Oxford: Clarendon Press, 2003.

Shinn, Abigail. “'Extraordinary discourses of vnnecessarie matter:' Spenser’s Shepheardes Calender and the Almanac Tradition.” In Literature and Popular Culture in Early Modern England, ed. Matthew Dimmock and Andrew Hadfield, 137-150. Farnham: Ashgate, 2009.

Spenser, Edmund. Amoretti and Epithalamion. London, 1595. 
Spenser, Edmund. Edmund Spenser's Amoretti and Epithalamion: A Critical Edition, ed. Kenneth J. Larsen. Tempe, Arizona: Medieval \& Renaissance Texts \& Studies, 1997.

Spenser, Edmund. The Faerie Queene. London, 1590.

Spenser, Edmund. The Faerie Queene, ed. A. C. Hamilton. London: Longmans, 2007.

Spenser, Edmund. The Yale Edition of the Shorter Poems of Edmund Spenser, ed. William A. Oram et. al. New Haven and London: Yale University Press, 1989.

Stapleton, M. L. “Devoid of Guilty Shame: Ovidian Tendencies in Spenser's Erotic Poetry," Modern Philology 105.2 (2007), 271-99.

Tattersall, Ian. The Fossil Trail: how we know what we think we know about human evolution. Oxford: Oxford University Press, 1995.

The Seconde Tome of Homelyes. London, 1563.

Tribble, Evelyn B. Margins and Marginality: The Printed Page in Early Modern England. Charlottesville: University of Virginia Press, 1993.

Tyndale, William, The Obedience of a Christian Man [1528], ed. David Daniell. London: Penguin, 2000.

Udall, Nicholas. Floures for Latine spekynge selected and gathered oute of Terence, and the same translated in to Englysshe. London, 1534.

Vincent, Nicholas. The Holy Blood: King Henry III and the Westminster Blood Relic. Cambridge: Cambridge University Press, 2001.

Walker Bynum, Caroline. Wonderful Blood: Theology and Practice in Late Medieval Northern Germany and Beyond. Philadelphia: University of Pennsylvania Press, 2007.

Walker Bynum, Caroline. "Seeing and Seeing Beyond: The Mass of St. Gregory in the Fifteenth Century." In The Mind's Eye: Art and Theological Argument in the Middle Ages, ed. Jeffrey F. Hamburger and Anne-Marie Bouché, 208-40. Princeton: Princeton University Press, 2006. 
Wall, Wendy. The Imprint of Gender: Authorship and Publication in the English Renaissance. Ithaca and London: Cornell University Press, 1993.

Walsham, Alexandra. "Jewels for Gentlewomen: Religious Books as Artifacts in LAte Medieval and Early Modern England.” In The Church and the Book, ed. R. N. Swanson, 123-42.

Woodbridge, D.S. Brewer, 2004.

Walsham, Alexandra. "Footprints and Faith: Religion and the Landscape in Early Modern Britain and Ireland." In God's Bounty: The Church and the Natural World, ed. Peter Clarke and Tony Claydon, 169-83. Woodbridge: D.S. Brewer, 2010.

Walsham, Alexandra. The Reformation of the Landscape: Religion, Identity and Memory in Early Modern Britain and Ireland. Oxford: Oxford University Press, 2011.

White, Paul. Jodocus Badius Ascensius: Commentary, Commerce and Print in the Renaissance. Oxford: Oxford University Press, 2013.

Wood, Christopher. Forgery, Replica, Fiction: Temporalities of German Renaissance Art. Chicago: University of Chicago Press, 2008.

Worm, Andrea. "Steine und Fußspuren auf dem Ölberg Zu zwei ungewöhnlichen Moitven bei Darstellungen der Himmelfahre Christi,” Zeitschrift für Kunstgeschichte, 66. Bd., H. 3 (2003), 297-320.

\footnotetext{
${ }^{1}$ Derrida, 1997, 84.

${ }^{2}$ Goldberg, 86 and passim; Rowe, Karim Cooper, 11-39.

${ }^{3}$ Harrison; Tattersall, 148-58.

${ }^{4}$ Ashton et al.

${ }^{5}$ Ingold, 2015, 62.
} 
${ }^{6}$ Leggatt, 45.

${ }^{7}$ Ibid.

${ }^{8}$ Davenport; Shepard, 224-26; Hindle.

${ }^{9}$ Gordon, 152-54.

${ }^{10}$ Norton, fol. $29^{\mathrm{r}}$.

${ }^{11}$ Campbell; Mayor and Sarjeant; Bord.

${ }^{12}$ Walsham, 2010, 171.

${ }^{13}$ Walsham, 2010, 172; Walsham, 2011, 40, 55, 104; Bord, 58-91.

${ }^{14}$ de Grazia, 83.

${ }^{15}$ Ibid., 82.

${ }^{16}$ Ingold and Vergunst, 8.

${ }^{17}$ Ingold, 2004.

${ }^{18}$ de Grazia and Stallybrass, 280; Calhoun.

${ }^{19}$ McLeod, 2011, 150.

${ }^{20}$ Gaskell, 218.

${ }^{21}$ McLeod, 2000, 184-7.

${ }^{22}$ Oxford English Dictionary, s.v. "footprint," n. ; s.v. "footing," $n$. 1-2, 4 ; s.v. "footstep," $n$. 1-4; see also s.v. "footfall." $n$.

${ }^{23}$ Snoek, 9-30.

${ }^{24}$ Ibid., 22.

${ }^{25}$ Ibid., 12-14, 178-9; Belting, 59.

${ }^{26}$ Munday, sig. E3 .

${ }^{27}$ Wood, 53-56.

${ }^{28}$ Calvin, sig. B2v

${ }^{29}$ Walker Bynum, 2007, 77; Belting, 224. 
${ }^{30}$ Snoek; Rubin; Beckwith; Walker Bynum, 2007; Vincent.

${ }^{31}$ Arnold, fol. 57 ; Calvin, sig. E1 ${ }^{\mathrm{r}}$.

${ }^{32}$ Morris, 126.

${ }^{33}$ Desjardin, 56-58; Fritz, 11-15; Worm, 307-8.

${ }^{34}$ Fritz, 11-15; Wilkinson, 100-01, 166-7; Desjardins.

${ }^{35}$ Morris, 126.

${ }^{36}$ Fritz, 16-20; Desjardins, 62-63; Nichol, 126; Worm, 311-14.

${ }^{37}$ Pon, 2015, 64.

${ }^{38}$ Fritz, 34.

${ }^{39}$ Schottus, II, 199.

${ }^{40}$ Calvin, sig. E1r.

41 “Lapidem de impressione pedis Christi caelos ascendentis," Flete, 69; Vincent, 12 n21.

${ }^{42}$ Kühnel et al; Wood, 332-40.

${ }^{43}$ Schiller, 2:189-215; Denny Brown and Cooper; Walker Bynum, 2007, 13, 182-3, 201.

${ }^{44}$ Schiller, 2 figs. 659, 716; Walker Bynum, 2006, fig. 8; Mittelrhein-Museum Koblenz,

Malerei M36. See also Berliner figs 4, 14.

${ }^{45}$ O Vernicle, 81-2; Nichols, 2009, 2014.

${ }^{46}$ Nichols, 2014, 123.

${ }^{47}$ Wood, 218.

${ }^{48}$ Parshall and Shoch, no.32, 144-7.

${ }^{49}$ Ibid., 146-7.

${ }^{50}$ Walker Bynum, 2006.

${ }^{51}$ Pon, 2015, 58-60.

${ }^{52}$ Koerner, 1995, 80; Hamburger 317-18. Belting, 208-224.

${ }^{53}$ Koerner, 1995, 83. 
${ }^{54}$ Pon, 2015, 66. Parshall and Shoch, no.70.

${ }^{55}$ Koerner, 1995, 90-95; Mukerji, 30-78.

${ }^{56}$ Landau and Parshall, 170-75.

${ }^{57}$ Pon, 2004, 65-66, 39-66.

${ }^{58}$ Schapiro.

${ }^{59}$ Deshman; Worm. Stained glass examples include the churches: All Saints, Pavement, York; St Mary Magdalene, Newark; St Peter and Paul, East Harling, Norfolk; St Mary’s, Elland, West Yorkshire.

${ }^{60}$ Parshall and Shoch, no.20d, 107; Field, fig. 11, 213; Hodnett, nos. 243, 331, 672, 2098, 2346.

${ }^{61}$ Cited in Deshman, 528.

${ }^{62}$ Areford, 130-41.

${ }^{63}$ Bartram, 239.

${ }^{64}$ Pon, 2004, 69-73, 137-54; Koerner, 2002, 25; Bartram 247-8.

${ }^{65}$ Landau and Parshall, 203-05; Anderson and Talbot, 180-87 nos. 60-99; Bartram, 223, 233 4.

${ }^{66}$ McDonald, 149, 186; Goris and Marlier, 58.

${ }^{67}$ Bartram, 223-82.

${ }^{68}$ Wood, 99-100.

${ }^{69}$ Scribner , 148-89.

${ }^{70}$ The name derives from the unusual Latinisation of his hometown Asche. Badius selected Ascensius rather than the more proper Ascensis, to give a closer play on Ascensio (Ascension). This second version of the colophon, in use 1520-28, gives particular prominence to the foot and can be seen as a response to the acheiropoietic aspects of the Dürer image. Renouard, I: 4-8, 42-7; White, 8 . 
${ }^{71}$ Celenza, 367.

${ }^{72}$ Cummings, 105.

${ }^{73}$ Erasmus, 1529, sig. A5 ${ }^{\mathrm{v}}-\mathrm{A} 6^{\mathrm{r}}$.

${ }^{74}$ Moshenka, 18.

${ }^{75}$ Cummings, 106.

${ }^{76} 1529$ (STC 10493), 1536 (STC 2835.2), 1542 (STC 2848), 1549 (STC 2856) and 1550

(STC 2821); Devereux.

${ }^{77}$ Seconde Tome of Homelyes, sig. Rrr4 ${ }^{\mathrm{v}}$.

${ }^{78}$ Cummings, 109.

${ }^{79}$ Rublack, 149-50.

${ }^{80}$ Seconde Tome of Homelyes, sig. Rrr4 ${ }^{\mathrm{v}}$.

${ }^{81}$ Moshenka, 24-5; Walsham, 2004.

${ }^{82}$ Aston, 1995; Aston, 2010, 28.

${ }^{83}$ Erasmus, 1534, sig. C4v .

${ }^{84}$ Tyndale, 25. The Exhortation was published separately in 1534 (STC 10493.5) and 1548 (STC 10494.5) as well as in a joint edition with the Paraclesis in 1534 (STC 10494). The similarity in titles has led to confusion of the two distinct texts, with the translation by Robert M Adams, wrongly identifying the work as the Preface to the third edition of the New Testament (1522). Erasmus, 1989, 118, 127.

${ }^{85}$ Erasmus, 1516, sig. BBB $1^{\text {r }} ; 1522$, sig. B $1^{\text {r-v }}{ }^{\mathrm{v}}$.

${ }^{86}$ Udall, fol. $51^{\mathrm{v}}$.

${ }^{87}$ Erasmus, 1522, sig. B1 ${ }^{\text {r }}{ }^{\mathrm{v}}$.

${ }^{88}$ Erasmus, 1534, sig. F7' Jardine; Grafton, 156-9.

${ }^{89}$ Erasmus, 1534, sig. F7 .

${ }^{90}$ Freedberg, 1976, 78-81; Saunders; Aston, 1993, 54-66; Bangs. 
${ }^{91}$ A woodcut copy of the image with Spanish text (BMPD 1913, 0418.1.) from c.1570 is extant in which the copyist, perhaps working with a late impression from a worn plate, looks to have missed the detail of the footprints, requiring the insertion of two crude sections depicting clusters of footprint into the original block.

92 Aston, 1993; Bangs.

${ }^{93}$ Daniels Siftyng.

${ }^{94}$ Compare STC nos. 3413; 3414; 4104; 19869.

95 Ariosto, sig. A1 ${ }^{\text {r }}$; Knapp, 154-55.

${ }^{96}$ Although first published in 1561, Gascoigne worked from the 1573 edition, Prouty and Prouty.

${ }^{97}$ Austen, 105-15; Hamrick; Bates 111-145.

${ }^{98}$ McLeod, 2000, 159.

${ }^{99}$ Ginzburg, 103.

${ }^{100}$ Ginzburg, 103; Eamon.

${ }^{101}$ Gascoigne, 1575, 61.

102 Wall, 243-50.

${ }^{103}$ Gascoigne, 1573, 398.

${ }^{104}$ Gascoigne, 1575, 62.

${ }^{105}$ Du Fouilloux has merely "Les vieux Cerfz on communément les cognoissances qui s'ensuyuent" (sig. H3 ${ }^{\mathrm{v}}$ ).

${ }^{106}$ Hence no bleedthrough is visible in the eebo images from the Huntington Library copy. While modern conservation techniques place an emphasis on preserving the integrity of the printed page, historic repairs generally placed a greater emphasis on the repair itself, or strengthening aspects of the treatment, with less regard for such side-effects. In addition, 
some materials used in these early repairs can age and discolour, and what was once visible may become less so over time.

${ }^{107}$ Fleming, 2016, 54.

${ }^{108}$ Derrida, 1997, 65.

109 Austen, 10-11.

${ }^{110}$ Bath.

${ }^{111}$ Luborsky, 1981, 1988; Henninger.

112 McCanles; McCabe, 2000.

${ }^{113}$ Bland, 100; McCabe, 2000, 37.

${ }^{114}$ Nicholson, 106-8

${ }^{115}$ McCanles; McCabe, 1997, 200; Tribble, 72-87.

${ }^{116}$ Scott Warren, 158-63.

${ }^{117}$ Bland, 108-113.

${ }^{118}$ Blank, 100-125; Shinn, Luborsky, 1981.

${ }^{119}$ Spenser, 1590, 186; 2007, II.Pro.4, 11.1-5.

${ }^{120}$ Spenser, 1590, 5; 2007, I.i.7, 1.8 .

${ }^{121}$ Spenser, 2007, IV.ii.34, 1.8.

${ }^{122}$ Grogan, 104.

${ }^{123}$ Bates, 244, 238-324.

${ }^{124}$ Wall, 47

${ }^{125}$ Nelson, 101-2.

${ }^{126}$ Bland, 114-22; Wall, 71-3.

${ }^{127}$ Fleming, 58.

${ }^{128}$ On Ponsonby and Spenser see Hadfield, 236-8.

${ }^{129}$ Dunlop; Johnson; Spenser, 1997. 
${ }^{130}$ Kaske; King, 142-82; Spenser, 1997.

${ }^{131}$ Fukuda.

${ }^{132}$ Kaske, 280.

${ }^{133}$ Edwards; Stapleton, 282.

${ }^{134}$ Ovid, III.523.

${ }^{135}$ Brooks, 193-7.

136 Prescott.

${ }^{137}$ Johnson; Spenser, 1997, 10-12.

${ }^{138}$ Spenser, 1997, 212-3.

${ }^{139}$ Spenser, 2007, VI.x.10, 1.4. 